\title{
Update on the impact of type 2 diabetes mellitus on bone metabolism and material properties
}

\author{
Ann-Kristin Picke ${ }^{1}$, Graeme Campbell ${ }^{2}$, Nicola Napoli ${ }^{3,4}$, Lorenz C Hofbauer ${ }^{5}$ and Martina Rauner ${ }^{5}$ \\ ${ }^{1}$ Institute of Comparative Molecular Endocrinology, Ulm University, Ulm, Germany \\ ${ }^{2}$ Institute of Biomechanics, TUHH Hamburg University of Technology, Hamburg, Germany \\ ${ }^{3}$ Diabetes and Bone Network, Department Endocrinology and Diabetes, University Campus Bio-Medico of Rome, Rome, Italy \\ ${ }^{4}$ Division of Bone and Mineral Diseases, Washington University in St Louis, St Louis, Missouri, USA \\ ${ }^{5}$ Department of Medicine III \& Center for Healthy Aging, Technische Universität Dresden, Dresden, Germany
}

Correspondence should be addressed to M Rauner: martina.rauner@ukdd.de

\begin{abstract}
The prevalence of type 2 diabetes mellitus (T2DM) is increasing worldwide, especially as a result of our aging society, high caloric intake and sedentary lifestyle. Besides the well-known complications of T2DM on the cardiovascular system, the eyes, kidneys and nerves, bone strength is also impaired in diabetic patients. Patients with T2DM have a $40-70 \%$ increased risk for fractures, despite having a normal to increased bone mineral density, suggesting that other factors besides bone quantity must account for increased bone fragility. This review summarizes the current knowledge on the complex effects of T2DM on bone including effects on bone cells, bone material properties and other endocrine systems that subsequently affect bone, discusses the effects of T2DM medications on bone and concludes with a model identifying factors that may contribute to poor bone quality and increased bone fragility in T2DM.
\end{abstract}

\section{Key Words}

- diabetes

- bone

\section{Introduction}

The prevalence of diabetes mellitus is increasing worldwide with diabetes-related complications accounting for up to $60-70 \%$ of health-care costs related to diabetes $(1,2)$. Besides the well-known renal and cardiovascular complications, the increased risk for fragility fractures has recently been recognized as an important complication of both type 1 and type 2 diabetes mellitus (T1DM, T2DM) $(3,4,5)$. While type 1 diabetics have low bone mineral density and a six- to sevenfold higher risk for fractures, type 2 diabetics have normal to high bone mineral density and up to threefold higher fracture risk $(6,7,8)$. Despite the similarity of chronic hyperglycemia, T1DM and T2DM have distinct pathophysiological mechanisms, which may differently affect bone metabolism. In both cases, the underlying mechanisms of poor bone strength are not well understood. Considering that T2DM accounts for the majority of diabetes cases (>90\%), this review will focus on summarizing the current knowledge on mechanisms that contribute to bone fragility in T2DM.

Mechanisms that lead to bone fragility in T2DM are manifold and encompass direct and indirect effects of T2DM on bone. Several studies have shown that T2DM in humans and animals is associated with suppressed bone formation and with negative effects on the mechanosensing properties of osteocytes, while effects on bone resorption are less consistently described. In humans, biochemical markers and bone histomorphometry reveal a low bone turnover in T2DM $(9,10,11,12,13)$. In animals, however, low bone formation is also a characteristic of T2DM, while bone resorption parameters are usually increased $(14,15,16,17,18)$. At a structural level, the accumulation of advanced glycation end (AGE) products
This work is licensed under a Creative Commons Attribution-NonCommercial 4.0 International License. ded from Bioscientifica.com at 04/25/2023 11:56:24PM 
under diabetic conditions has been proposed to alter collagen structure and contribute to impaired material properties. Along those lines, patients with T2DM have increased cortical porosity, which may further contribute to reduced bone strength (Fig. 1). Besides these direct effects of high glucose levels on bone, the increased risk of fractures may also be explained by the presence of diabetic complications on the eyes, kidney and nerves, decreased physical activity, lower vitamin D levels and higher risk of falls. In particular microvascular impairment, which may also affect the bone vasculature, and increased bone marrow adiposity (19) (Fig. 1) may be key factors that contribute to skeletal alterations and translate into a higher incidence of fractures, delayed fracture healing and delayed osseointegration.

\section{Structural and material properties of bone in T2DM}

Patients with T2DM have a particularly high risk to fracture their hip, wrists and feet, and fracture risk further increases with disease duration, insulin intake and poor control of hyperglycemia $(6,20,21,22)$. While in postmenopausal osteoporosis there is a clear association between low bone mineral density and high risk of fracture; most studies in diabetics paradoxically report either similar bone mineral density or 5-10\% increase in bone mineral density of patients with T2DM compared to nondiabetic controls (7). At a microstructural level, MRI and high-resolution peripheral quantitative computer tomography studies indicate increased cortical porosity,

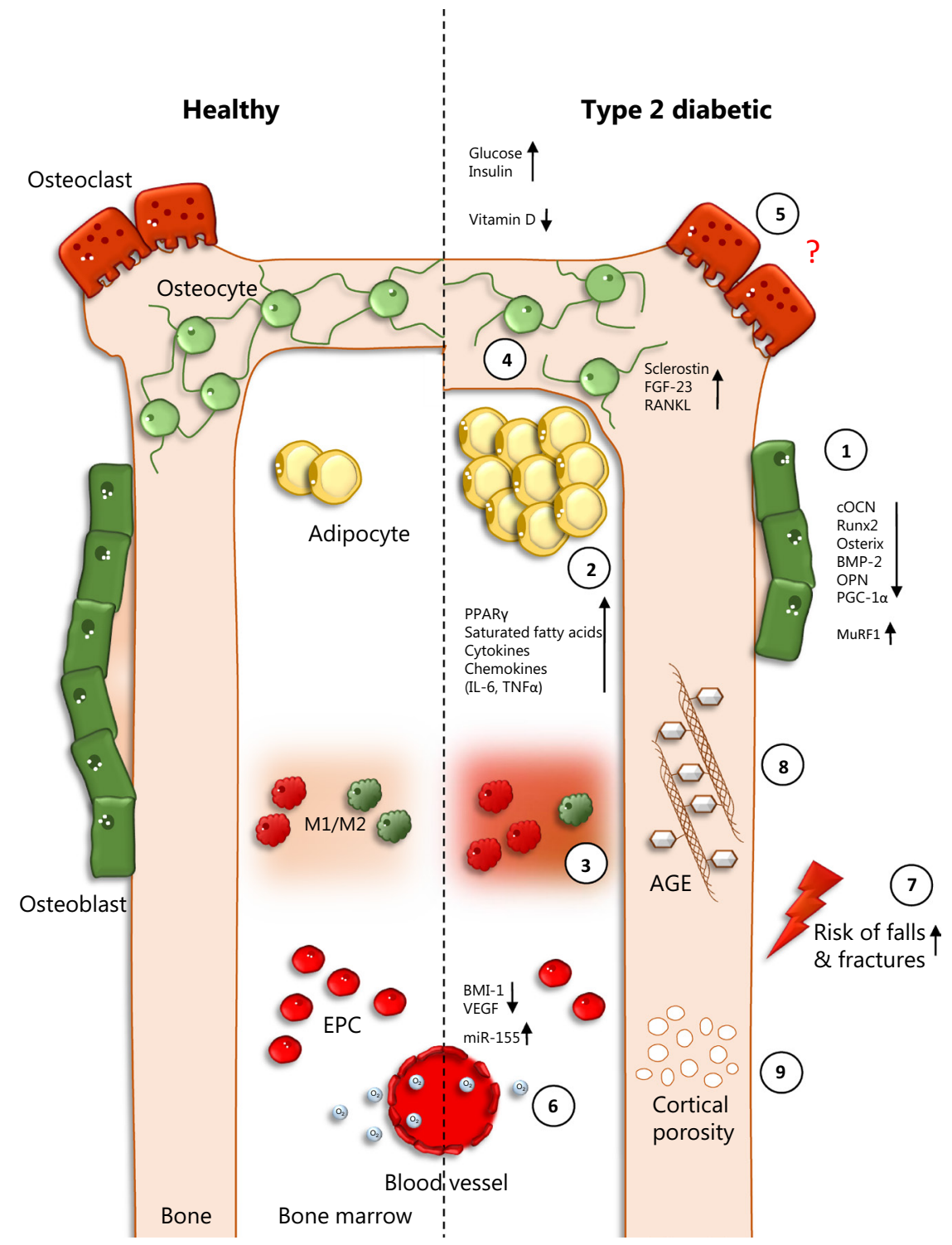

Figure 1

Effects of T2DM on bone homeostasis. T2DM negatively affects trabecular bone mass, while cortical bone mass is increased. (1) The number and function of bone-forming osteoblast is reduced. In addition, vitamin $D$ serum levels are decreased, which alters calcium and phosphate homeostasis. (2) Osteoblasts derive from MSC that favor differentiating into fat-storing adipocytes in T2DM leading to bone marrow adiposity and increased expression of cytokines and chemokines as well as to an elevated amount of free unsaturated fatty acids. (3) This results in increased inflammation leading to accumulation of pro-inflammatory M1 macrophages and reduced switch into anti-inflammatory $\mathrm{M} 2$ macrophages. (4) The network of osteocytes is reduced due to an increased apoptosis rate. They increase their expression of sclerostin, an inhibitor of osteoblast function, and RANKL, a promoter of osteoclastogensis. FGF-23, a phosphaturic hormone, is additionally increased. (5) Effects on osteoclasts are controversial in the literature, but T2DM is generally accepted to reduce bone turnover and thus also osteoclast function. (6) The amount of endothelial progenitor cells (EPC) is reduced in T2DM leading to vessel permeability. In addition, T2DM causes microhypoxia in bone niche, which in turn increases inflammation. (7) T2DM patients have an increased risk of falls and fractures due to reduced bone quality indicated by (8) an increased formation of advanced glycation end-products (AGEs) and (9) cortical porosity.

https://ec.bioscientifica.com https://doi.org/10.1530/EC-18-0456 (c) 2019 The authors Published by Bioscientifica Ltd

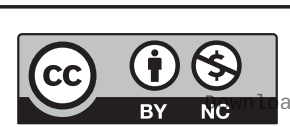

This work is licensed under a Creative Commons Attribution-NonCommercial 4.0 International License. ded from Bioscientifica.com at 04/25/2023 11:56:24PM 
especially in patients with fractures and/or microvascular disease $(23,24,25)$. Accordingly, bone strength estimated by finite element modeling at the distal radius is lower in patients with T2DM and correlates negatively with cortical porosity (26). Finally, microindentation on the tibia of patients with T2DM revealed low bone material strength $(27,28,29)$. Taken together these studies provide evidence that the biomechanical integrity of the skeleton is reduced in T2DM, and this is a result of an inferior microstructure and material properties of the bone tissue. Interestingly, the trabecular bone score, a parameter that evaluates the pixel gray-level variations in lumbar spine dual-energy X-ray absorptiometry images and is related to bone microarchitecture independent of bone mineral density, appears to pick up those microarchitectural differences, being consistently low in patients with T2DM $(30,31,32)$.

The effect of T2DM on bone material properties may not be limited to porosity, as alterations in bone collagen also occur. It is unclear to date, however, whether these significantly contribute to a weakened bone material in diabetic patients. One alteration of collagen that is highly researched is the formation of AGEs. AGEs are modifications of proteins that become nonenzymatically glycated after exposure to sugars (33), and are elevated in individuals with hyperglycemia. AGE cross-links alter the properties of proteins such as collagen and laminin $(34,35)$ and, in bone, this leads to an increased brittleness of the otherwise elastic collagen fibers $(36,37)$ and reduces the tissue toughness $(38,39)$. AGEs can also interfere with osteoblast $(40,41)$ and osteoclast functions (42), and may also impair osteocyte response $(43,44)$. AGEs may therefore play an important role in both bone material properties and bone turnover in T2DM $(45,46,47)$.

In animal models of T2DM, some studies have reported increased AGE content in the bone tissue $(48,49)$, while other studies have reported no difference in AGEs but alterations in the collagen structure (50) and increased collagen maturity (51). Since levels of AGEs in the bone tissue cannot be measured noninvasively in patients, surrogates, such as serum or urine levels, are typically used. Due to the fluorescent nature of AGEs, skin fluorescence has also been reported as a surrogate measure and has been associated with the reduction of bone material strength assessed with indentation tests (29). To date, relatively few studies have investigated the accumulation of AGEs in T2DM patients, in particular, in the bone tissue and those that have report conflicting results. Serum levels of the AGE pentosidine in T2DM patients have been reported to be higher than (52) and similar to $(27,53,54)$ nondiabetic controls. A recent study that examined AGEs in the bone tissue from femoral neck specimens excised during total hip replacement surgery reported increasing trends of AGE levels in the cortex, but not trabecular bone from T2DM patients, despite no significant differences in serum levels of pentosidine or total AGEs between groups (27). Although the authors do report significant correlations between bone and serum AGEs in this study, these results highlight that surrogate measures may not be sufficient as diagnostic tools for assessing the material properties of T2DM bone. Nevertheless, pentosidine levels in the urine have also been associated with increased vertebral fracture prevalence in T2DM patients and lower trabecular bone score, but not in controls $(53,55)$, which along with the microstructural studies reporting increased porosity, suggests that a subset of T2DM patients may be at a particularly high risk of fracture.

\section{Mechanisms of bone fragility in T2DM}

In addition to the microstructural alterations in organic and inorganic bone components, T2DM directly affects the differentiation and function of bone cells, and modifies the bone microenvironment in such a way that secondary negative effects on bone cells occur (e.g. reduced blood flow in bone, increased presence of fat in the bone marrow, inflammation). The mechanisms of how T2DM exerts these negative effects on bone cells will be discussed in this article.

\section{Direct effects on bone cells}

\section{Osteoblasts and bone formation parameters}

Osteoblasts derive from mesenchymal stromal cells (MSC) and are essential for bone formation as they synthesize collagen and mineralize the organic matrix. T2DM individuals have high serum glucose concentrations, elevated post-load insulin levels and a high body mass index (56). In homeostasis, insulin promotes osteoblast differentiation leading to an increased expression of the carboxylated form of osteocalcin. Similarly, mouse models showed that glucose is an important source of energy for osteoblasts to allow for the production of collagen fibers (57). As previously reviewed, in T2DM, however, high levels of glucose suppress osteoblast differentiation (58). Also, carboxylated osteocalcin serum concentrations are reduced and inversely associated with fasting glucose levels and insulin resistance (reviewed in 59). In line, a reduced osteoid volume, osteoid thickness and osteoblast

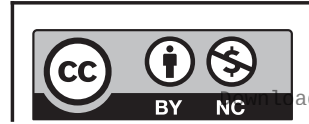

This work is licensed under a Creative Commons Attribution-NonCommercial 4.0 International License. ded from Bioscientifica.com at 04/25/2023 11:56:24PM 
surface was detected in iliac crest bone samples in male and female T2DM individuals (11). Furthermore, the serum bone formation markers procollagen type 1 $\mathrm{N}$-terminal propeptide and alkaline phosphatase (ALP) have been found mostly unaltered or reduced in type 2 diabetic individuals, even though increased levels of ALP have also been reported (reviewed in 9, 60, 61, 62, 63, 64).

As mentioned above, high glucose concentrations lead to the creation of AGEs in bone matrix. Human osteoblasts treated with high glucose concentration and/or AGEs show a reduced expression of pro-osteogenic markers such as Runx 2 and Osterix $(65,66)$. More critically, AGEs increase the rate of apoptosis of osteoblasts and its precursor cells $(67,68)$.

Wnt signaling and the bone morphogenetic pathway (BMP) are critical for osteoblast differentiation. Osteogenic cell lines show reduced Wnt activity, which is associated with reduced osteogenic differentiation, after stimulation with high glucose concentrations $(69,70$, 71). Wnt signaling is also one of the key pathways that regulate the osteoblast vs adipocyte fate decision of MSCs. In T2DM, osteogenesis is reduced while adipogenesis is increased resulting in bone marrow adiposity due to increased PPAR $\gamma$ signaling, which is at least partially Wntdependent (reviewed in 4, 72, 73, 74, 75). Other pathways determining osteoblast vs adipocyte fate in T2DM are discussed in section 'Indirect T2DM effects on bone cells'. Besides reduced Wnt signaling, a decreased expression of BMP-2 and osteopontin was also found in osteoblasts obtained from type 2 diabetic rats (76). In accordance with suppressed Wnt signaling in vitro, serum concentrations of the Wnt inhibitors, sclerostin and DKK-1, are increased in T2DM $(12,77)$ as are serum levels of active transforming growth factor $\beta$ (TGF- $\beta$ ), which is associated with the development of diabetic nephropathy (78). Culturing pre-osteoblasts in this T2DM serum leads to reduced ALP activity and diminished matrix mineralization $(66,79)$.

Finally, the fatty acid composition has a large impact on osteoblast function. Nonesterified fatty acids induce apoptosis in osteoblasts, which is associated with downregulation of peroxisome proliferator-activated receptor $\gamma$ coactivator 1- $\alpha$ (PGC-1 $\alpha)$ and upregulation of the muscle ring finger protein-1. Depletion of muscle ring finger protein- 1 or upregulation of PGC- $1 \alpha$ in diabetic mice restored bone mass to WT level without affecting T2DM (80). Not only the amount but also the saturation of fatty acids affects osteoblast function. T2DM has an increased amount of saturated compared to monounsaturated fatty acids leading to reduced osteoblast differentiation and mineralization capacity as well as increased apoptosis rate due to their lipotoxic effect (81).

Taken together, T2DM exerts direct negative effects on osteoblasts via several molecular mechanisms (Fig. 1). Moreover, it favors the fate decision of MSCs to turn into adipocytes, which further impairs osteoblast function, bone formation and bone mass.

\section{Osteocytes}

During bone formation, a proportion of osteoblasts embed themselves into the bone matrix they produced and differentiate into mechanosensing osteocytes. For the exchange of oxygen and nutrients, they are connected via canaliculi and form a sophisticated network through the bone (82). This network is impaired in T2DM and even under high-fat diet conditions (83). The osteocyte density is reduced and the number of empty lacunae is increased likely due to increased osteocyte apoptosis under high glucose conditions. This subsequently leads to an impaired mechanosensing response to oscillatory shear stress in vitro $(44,84)$. Osteocytes coordinate osteoblast and osteoclast function via secretion of the Wnt inhibitor sclerostin and the promoter of osteoclastogenesis, receptor activator of NF- $\mathrm{kB}$ ligand (RANKL), respectively $(85,86)$. In vitro, high concentration of glucose and incubation with AGEs increase both sclerostin and RANKL expression (44). In T2DM patients, sclerostin serum levels are elevated and associated with glycated hemoglobin levels and insulin resistance $(87,88)$. Lastly, osteocytes regulate phosphate homeostasis by expression of fibroblast growth factor-23. This factor is also involved in the progression of atherosclerosis through its effects on endothelial cell function and is a predictor of cardiovascular disease risk $(89,90)$. Accordingly, fibroblast growth factor-23 serum concentrations are increased in T2DM patients that have high risk for developing cardiovascular diseases (91).

\section{Osteoclasts}

For a healthy bone status, bone formation by osteoblasts and bone resorption by osteoclasts needs to be balanced. In T2DM, osteoblast function is disturbed and osteoclast activity is altered leading to impaired bone remodeling. However, the literature on osteoclasts is controversial. Serum levels of the bone resorption marker collagen type I C-terminal telopeptide (CTX) are reported to have either increased or decreased in T2DM cohorts (reviewed in 60). A meta-analysis of 66 studies however revealed an overall 
low bone turnover with low levels of CTX in diabetic patients (13). In type 2 diabetic rodents (TallyHo mice and ZDF rats), bone resorption parameters are mostly increased (serum CTX or TRAP, histological numbers of osteoclasts) $(16,17,76,92)$.

Culturing osteoclast-like Raw264.7 cells in high glucose concentration reduces the expression of osteoclast-specific genes including nuclear factor of activated $T$ cells, cytoplasmic 1, tartrate-resistant acid phosphatase and osteoclast-associated receptor. In addition, high glucose decreases cell proliferation and cell size due to suppression of the formation of the osteoclast-specific actin ring (70). When mimicking hyperglycemia and hyperinsulinemia combined, osteoclast differentiation and gene expression of marker genes are downregulated (93).

For osteoclastogenesis to occur, RANKL must activate its receptor RANK located at the surface of pre-osteoclasts. Osteoprotegerin (OPG) acts as a decoy receptor of RANKL and thereby inhibits osteoclast differentiation. Both, RANKL and OPG are highly expressed by osteoblasts and osteocytes. Osteoblasts cultured in high glucose concentration increase both RANKL and OPG expression $(70,94)$ while the direct effect of RANKL on osteoclastogenesis is reduced (95). In addition, incubation of osteocyte-like MLO-Y4-A2 cells with high glucose concentration and AGEs highly increases RANKL expression (44).

Besides osteogenic cells, other cells contribute to RANKL and OPG production under certain, for example, inflammatory conditions. T2DM patients suffer from body and bone marrow adiposity (reviewed in 72) which is associated with increased TNFo serum level (96). Human bone marrow adipocytes express more RANKL and less OPG when additionally treated with TNF $\alpha$ resulting in an increased resorption capacity of osteoclasts (97). In addition, TNF $\alpha$ can induce osteoclastogenesis in combination with macrophage colony-stimulating factor only (98) and also potently increases osteoclastogenesis when low RANKL concentrations are present (99).

Finally, T2DM is associated with a higher amount of saturated fatty acids that reduce osteoclastogenesis, but increase osteoclast survival by production of macrophage inflammatory protein $1 \alpha$ leading to activation of NF-kB $(100,101)$. Taken together, several diabetes-derived factors have an impact on osteoclasts, yet, sometimes in opposing ways. Thus, current data do not allow forming a general statement on the role of T2DM on osteoclasts.

\section{Indirect T2DM effects on bone cells}

\section{Bone marrow adiposity and MSC fate}

Recently, bone marrow fat was discovered as an endocrine organ $(72,102)$. Even though it is known to impact energy homeostasis and bone turnover via secretion of adiponectin, still its origin, detailed characterization and function remain largely elusive. Studies in T2DM patients show controversial results. The vertebral bodies of type 2 diabetic men and postmenopausal women show a higher marrow adipose tissue (MAT) content compared to controls. MAT is negatively correlated with bone mineral density and positively with visceral adipose tissue and HbA1c values $(74,103)$. However, two other studies with T2DM patients showed no difference in MAT. Nonetheless, MAT was associated with HbA1c in one study (104) and with fractures in another $(103,105)$. High MAT mass is further associated with increased PPAR $\gamma$ signaling and accordingly treatment of T2DM patients aged with the PPAR $\gamma$ agonist pioglitazone increased MAT in vertebra and femur (73).

Similar to humans, bone marrow adiposity increases in rodents with T2DM. Among others, diabetic ZDF rats and TallyHo mice show an increased bone marrow fat mass (up to 50-fold) compared to nondiabetic controls in vertebra and long bone, while bone mass is decreased (17, 76, 106, 107). In addition, feeding C57BL/6 mice with high-fat diet over several months results in an accumulation of bone marrow adiposity and a reduced bone mass (108). Interestingly, control of blood glucose affects MAT. While fat volume in the vertebra is unaltered by insulin therapy in diabetic ZDF rats, the adipocyte area, but not the size of adipocytes in the tibia, is reduced (107).

Mechanistically, high glucose concentrations prime MSCs to reprogram autocrine Wnt signaling resulting in an increased WNT11 expression and activation of PKC leading to an elevated adipogenesis (109). Further, Wnt5a plays an important role in MSC fate decision. Wnt5adeficient mice express less LRP5/6 leading to a reduced Wnt/ $\beta$-catenin signaling, which consequently reduces osteoblastogenesis while increasing adipogenesis (110). Similar pro-osteogenic and anti-adipogenic effects were detected for the Wnt ligands Wnt6, Wnt10a and Wnt10b $(111,112)$. In line, blocking $\beta$-catenin signaling leads to bone marrow adiposity and low bone mass (113). Recently, other factors were identified to control MSC fate decision. The nuclear transcription factor I-C increases adipogenesis when being overexpressed and thereby reduces osteoblastogenesis and vice versa when its expression is 
inhibited (114). In addition, the cell surface protein Thy-1 - also known as cluster of differentiation 90 - controls MSC differentiation by promoting osteoblastogenesis and decreasing whole body adipogenesis in vivo (115). In patients with osteoporosis and obesity, both characterized by altered bone homeostasis, serum concentrations of soluble THY-1 are reduced indicating clinical relevance of this factor (115). Therefore, bone marrow adipogenesis in T2DM must result from multifactorial reasons such as altered Wnt signaling, modified expression of adipokines, transcription factors and surface proteins as well as augmented glucose and insulin signaling (116).

\section{Inflammation}

Type 2 diabetic patients are overweight and adiposity gives rise to low-grade inflammation that negatively affects whole body metabolism and bone homeostasis (60). In T2DM patients, serum levels of pro-inflammatory cytokine interleukin 6 (IL-6) and high-sensitivity C-reactive protein are increased, which is associated with reduced concentration of osteocalcin (117). TNF $\alpha$, IL-1 and TGF- $\beta$ levels are also highly increased in overweight and insulin resistance indicating latent inflammation in T2DM (reviewed in 118, 119). Further, the amount of saturated fatty acids is increased (81). Stimulation of human osteoblasts with saturated fatty acids highly increases expression of IL-6 and the chemokines IL-8, and monocyte chemoattractant protein-1 (120). Finally, hypoxia is a novel mechanism participating in insulin resistance in adipose tissue of obese patients that exacerbates the pro-inflammatory activity of adipocytes $(121,122,123)$.

Inflammation activates immune defense by mobilization of macrophages. Increased body and bone marrow fat in T2DM attract monocytes via elevated chemokine expression such as leukotriene B4, macrophage inflammatory proteins, macrophage migration inhibitory factor and monocyte-chemotactic protein 3 . In fat depots, they differentiate into pro-inflammatory M1 macrophages and further express pro-inflammatory cytokines resulting in macrophage accumulation and activation of inflammatory reactions. This disturbs macrophage polarization leading to a reduced switch from pro-inflammatory M1 to anti-inflammatory M2 macrophages, which are important for tissue surveillance, remodeling functions and maintaining insulin sensitivity of white adipose tissue (reviewed in 124) (Fig. 1).

\section{Microangiopathy in bone}

A healthy status of vascularization is mandatory to provide all body cells with nutrients and oxygen. Also within the bone microenvironment, angiogenesis is important and in fact linked to osteogenesis (125). In diabetic mice, the blood flow and microvascular density in bone marrow is reduced and the amount of endothelial cells is decreased. They are functionally impaired as shown by a diminished capacity to migrate and to form networks, which leads to microangiopathy and increased vessel permeability $(126,127)$. RhoA-Rho-associated kinase signaling has been implicated in reduced vessel function as a result of reduced stem cell viability, mobilization and via elevated oxidative stress $(128,129)$. In line with that, T2DM patients have a reduced abundance of endothelial progenitor cells in the blood $(130,131,132,133)$. In human endothelial progenitor cells, levels of cell survival regulating microRNA miR-155 are increased resulting in elevated apoptosis, which is triggered by high glucose concentrations $(132,134)$. To mobilize endothelial progenitor cells from the bone marrow, nitric oxide synthase (eNOS) is necessary. Under diabetic conditions endothelial progenitor cells synthesize less nitric oxide due to a damaged eNOS-caveolin-1 complex $(135,136)$. This endothelial dysfunction is also associated with increased Dickkopf-1 serum levels that further negatively affect osteoblast differentiation (77).

In addition, T2DM alters adipokine expression. Adiponectin confers protection of endothelial cells and its serum concentration is reduced in diabetic individuals, which may lead to microangiopathy (reviewed in 137). In vivo, the decreased endothelial progenitor cell mobilization from bone marrow leads to less cell recruitment in ischemic tissue. Therefore, fewer endothelial progenitor cells participate in neovascularization in peripheral tissues, leading to organ dysfunction and impaired regeneration potential, such as seen in fracture healing in T2DM patients (138). These findings indicate that vascular dysfunction in diabetes has its origin in the bone marrow by depleting the stem cell niche.

\section{Treatment of diabetic bone disease}

Two strategies can be envisaged to treat diabetic bone disease. First, to control blood glucose levels and prevent secondary effects of T2DM, and second, by directly blocking bone resorption and restoring osteoblast
This work is licensed under a Creative Commons Attribution-NonCommercial 4.0 International License. ded from Bioscientifica.com at 04/25/2023 11:56:24PM via free access 
Table 1 Effect of antidiabetic and anti-osteoporosis treatments on bone.

\begin{tabular}{|c|c|c|c|c|c|c|c|c|}
\hline \multirow[b]{2}{*}{ Treatment } & \multicolumn{4}{|c|}{ Animal in vivo studies } & \multicolumn{4}{|c|}{ Human in vivo studies } \\
\hline & Bone formation & Bone resorption & $\mathrm{BMD}$ & Fracture healing & Bone formation & Bone resorption & BMD & Fracture risk \\
\hline \multicolumn{9}{|l|}{ Antidiabetic treatment } \\
\hline Metformin & $\uparrow$ & $\downarrow$ & $\uparrow^{*}$ & $\uparrow$ & $\downarrow /=$ & $\downarrow /=$ & $\uparrow /=$ & $\downarrow /=$ \\
\hline Thiazolidinediones & $\downarrow$ & $\uparrow$ & $\downarrow /=$ & $?$ & $\downarrow /=/ \uparrow$ & $\uparrow /=/ \uparrow$ & $\downarrow /=$ & $\uparrow /=$ \\
\hline Insulin & $\uparrow$ & $=$ & $\uparrow /=$ & $\uparrow$ & $=$ & $=$ & $=$ & $\uparrow /=$ \\
\hline Sulphonyl urea & $\uparrow$ & $\downarrow$ & $\uparrow$ & $?$ & $\uparrow /=$ & $\downarrow /=$ & $=$ & $\uparrow$ \\
\hline Incretins & $\downarrow$ & $\downarrow$ & $\uparrow /=$ & $?$ & $\downarrow /=$ & $\downarrow /=$ & $\uparrow /=$ & $\downarrow /=$ \\
\hline SGLT2 & $=$ & $\uparrow /=$ & $=$ & $?$ & $=$ & $\uparrow /=$ & $=$ & $\uparrow /=$ \\
\hline \multicolumn{9}{|c|}{ Anti-osteoporosis treatment } \\
\hline Bisphosphonates & $\downarrow^{*}$ & $\downarrow^{*}$ & $=$ * & $\uparrow * 1$ & $\downarrow$ & $\downarrow$ & $\uparrow /=$ & $\downarrow$ \\
\hline Anti-RANKL Ab & $\downarrow^{*}$ & $\downarrow^{*}$ & $\uparrow^{*}$ & $\uparrow * 1$ & $\downarrow^{* 1}$ & $\downarrow^{\star 1}$ & $\uparrow^{\star 1}$ & $\downarrow^{* 1}$ \\
\hline Intermittent PTH & $\uparrow$ & $\downarrow$ & $\uparrow$ & $\uparrow$ & $\uparrow$ & $\downarrow$ & $\uparrow$ & $\downarrow$ \\
\hline Anti-sclerostin $A b^{\#}$ & $\uparrow$ & $\downarrow$ & $\uparrow$ & $\uparrow$ & $\uparrow * 1$ & $\downarrow * 1$ & $\uparrow * 1$ & $\downarrow^{* 1}$ \\
\hline
\end{tabular}

*Only tested in type 1 diabetes; *1 only tested in nondiabetics; ${ }^{*}$ not yet approved.

$\downarrow$, decreased; $\uparrow$, increased; ?, not investigated; =, unaltered; BMD, bone mineral density; PTH, parathyroid hormone; SGLT2, sodium-glucose cotransporter 2 .

function. Both options will be discussed in this article (Table 1).

\section{Effects of antidiabetic treatments on bone}

\section{Metformin}

Metformin is taken orally and decreases production of hepatic glucose via inhibition of mitochondrial respiratory chain complex 1, while increasing insulin sensitivity and stimulating glucose uptake by activation of AMPactivated protein kinase ((139), reviewed in 140). In vitro and in vivo, metformin increases osteogenic induction and further enhances bone repair in rodents. In T2DM patients, metformin does not alter bone mineral density or fracture risk at spine, forearm or hip (reviewed in $6,140,141,142)$. Recently, it was shown that metformin therapy for 18 months does not alter spinal or hip bone mass, while trabecular bone score decreases in T2DM patients. Further, serum bone turnover markers P1NP and CTX are decreased by metformin $(30,143)$.

\section{Thiazolidinediones}

Thiazolidinediones (TZD) improve glycemic control and insulin sensitivity in T2DM. A common agent is rosiglitazone that activates PPAR $\gamma$ and improves insulin sensitivity in adipocytes by promoting adipogenesis and the accumulation of triglycerides into lipid droplets, thereby increasing adipose tissue amount (140). In vivo, TZD administration leads to bone marrow adiposity and reduces osteoblastogenesis resulting in bone loss. In line, T2DM patients with TZD treatment have increased bone marrow fat in the fourth lumbar vertebral body, reduced osteoblastogenesis and an increased fracture risk at the hip and wrist, which is generally more prominent in women $(73,144$, reviewed in 140,143$)$. It is interesting to note that TZD treatment is not associated with risk of fracture in men (meta-analysis). However, recently it was detected that rosiglitazone administration is not associated with alterations in bone turnover markers, while reducing bone formation in combination with metformin (143).

\section{Insulin}

T2DM is characterized by increased serum glucose and insulin concentration due to insulin resistance. With disease progression, insulin production decreases and patients need to be additionally treated with insulin. Daily insulin treatment of T2DM rats improved glycemic control, but did not improve trabecular bone mass while cortical bone mass increased, suggesting site-specific effects of insulin on bone. Additionally, bone defect regeneration improved up to control level after insulin administration (107). Human studies are lacking to evaluate the effect of insulin treatment on bone mass in T2DM. Nevertheless, studies show that T2DM patients treated with insulin have an unaltered to increased fracture risk at the hip, while men seem to be more prone than women (reviewed in $140,145,146)$. It is clear that insulin treatment has a positive effect on bone metabolism. Thus, the increased fracture risk may be explained by the higher rate of falls caused by hypoglycemic events. It is also worth to note that patients on insulin treatment may also have longer duration of disease and are more likely to have developed diabetes complications.
This work is licensed under a Creative Commons Attribution-NonCommercial 4.0 International License. ded from Bioscientifica.com at 04/25/2023 11:56:24PM via free access 


\section{Sulphonyl urea}

These medications have been used for more than 40 years, are inexpensive and still largely used in the diabetes clinic. Mechanism of action is based on increased release of insulin from the beta cell that is independent from glucose serum levels, implying a high risk of hypoglycemic events. Preclinical studies have excluded a direct effect of sulphonylureas at the bone level and, therefore, have been considered a safe option. However, more recent data have shown almost a doubled risk of hip fracture in treated patients, likely caused by higher frequency of hypoglycemic $(146,147,148)$ events.

\section{Incretins}

Glucose-dependent insulinotropic polypeptide (GIP) and glucagon-like peptide-1 (GLP-1) are two gastrointestinal hormones known as incretins, 'INtestine SeCRETion Insulin', secreted in response to nutrient intake. In order to compensate for low incretin effect in T2DM patients, two different therapeutic options have been developed, either by inhibiting dipeptidyl dipeptidase-4, an enzyme that rapidly inactivates GIP and GLP-1 (sitagliptin, vildagliptin, saxagliptin, linagliptin, alogliptin), or by GLP-1 mimetic drugs (liraglutide, exenatide, dulaglutide, albiglutide, lixisenatide). These medications improve glucose control with low risk of hypoglycemic events and can be safely used in the long term.

GLP-1 receptor knock-out mice show increased osteoclast numbers, bone resorption rate, bone fragility and low calcitonin levels, which increases after treatment with a GLP-1 receptor agonist (149). Treatment with GLP-1 analogues under normal or high glucose conditions in ovariectomized rats and mice for 16 weeks promoted bone formation and lowered bone resorption with a significant increase in femoral bone mineral density and strength $(150,151,152,153,154)$. In T2DM rodents, GLP-1 and exendin-4 treatment reduced serum bone remodeling marker while increasing bone mass only partially (155, 156, 157). Despite these promising preclinical results, clinical data have only shown a neutral effect on bone mineral density and no prospective data are available for fracture risk. In an attempt to fill this gap, different metaanalyses on randomized controlled trials, where fractures were noted as possible side effects, have been published with inconsistent results (158, 159, 160, 161). These studies are limited by different fracture definitions across studies and lack of radiographic control of the events. Women treated with liraglutide for 52 weeks lost $12 \%$ of initial body weight, had improved total, pelvic and arm/leg bone mineral content and P1NP levels, although methodological concerns have been raised (162). Risk of fracture has been shown to be neutral (HR 1.00 (95\% CI 0.83-1.19)) in a large clinical trial investigating the cardiovascular safety of saxagliptin vs placebo (163). In conclusion, although more clinical evidence is needed, GLP-1 agonists and dipeptidyl dipeptidase- 4 inhibitors seem to have a safe bone health profile.

\section{Sodium-glucose cotransporter inhibitors}

These new generation drugs selectively inhibit the renal sodium-glucose cotransporter 2 (SGLT2, the key transporter mediating glucose reabsorption by the kidney), thereby increasing urinary glucose excretion $(164,165)$. The first three SGLT2 inhibitors released in the market, namely canagliflozin, empagliflozin and dapagliflozin, have proven not only an antidiabetic effect but also significant reduction in cardiovascular risk, implying a wide use in both T1DM and T2DM. While in vivo and in vitro studies have not been consistent, clinical data have raised concerns on bone safety $(4,166)$. In fact, SGLT2 inhibitors increase phosphate tubular reabsorption and serum concentrations of parathyroid hormone and, in turn, bone (167). In two different randomized, double-blind, placebo-controlled studies, dapagliflozin has shown neutral effects on bone turnover and bone density $(168,169)$. A post hoc analysis from the EMPAREG study has also shown neutral effects on fracture risk for empagliflozin (170).

Data are less reassuring for canaglifozin which has been associated with higher bone loss, increased bone resorption and a higher incidence of fractures compared to non-canagliflozin treatment (2.7 vs $1.9 \%$ respectively) $(171,172)$. Although data on dapagliflozin and empagliflozin show a safe bone profile, data on canagliflozin are concerning and more studies are needed to clarify a possible class effect and reasons for discrepancy in terms of safety profile among these medications.

\section{Anti-osteoporosis treatments}

\section{Bisphosphonates}

Bisphosphonates are the first-line option to treat osteoporosis in postmenopausal women and men. Bisphosphonates bind to mineralized matrix with a high affinity and inhibit the resorption capacity of osteoclasts. This reduces bone turnover, increases bone mass and decreases fracture risk (reviewed in 173). Elderly postmenopausal, osteoporotic women with T2DM that

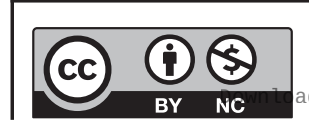


are treated with alendronate and calcium/vitamin D supplements are resistant against therapy effects shown by decreased total hip, femur neck and femur bone mineral density, while spine bone mineral density is unaltered (174). In contrast, when osteoporosis had been diagnosed recently, T2DM women benefited from bisphosphonate treatment by increased bone mineral density at the lumbar spine. However, bone remodeling markers such as CTX and ALP are decreased in T2DM, osteoporotic women with increased spine bone mineral density (reviewed in 175). In addition, treatment with bisphosphonates has a similar anti-fracture efficacy in diabetes patients compared with nondiabetic regarding non-vertebral fractures (reviewed in 176). Thus, even though bisphosphonate further suppress bone turnover, they may still be an effective therapy for patients with T2DM.

\section{Denosumab}

Denosumab is a monoclonal antibody targeted against RANKL, the key cytokine to drive osteoclastogenesis, which has been approved for the treatment of osteoporosis. Through its mechanism of action, inhibition of RANKL reduced bone resorption and therefore increased bone mass in rodents (177). In addition, the blockade of RANKL has been tested in preclinical models to improve glycemic status. A post hoc analysis of the freedom trial has shown that denosumab significantly lowers fasting serum glucose in naive patients with T2DM throughout the 3 years of observation vs placebo (178). Considering that the study was not designed for diabetes-related outcomes, more studies are needed to test efficacy of denosumab on glucose control. Nonetheless, phase II studies are ongoing to better define denosumab as a safe option to treat bone fragility in type 2 diabetic patients.

\section{Intermittent PTH treatment}

Intermittent PTH administration is commonly used in the clinics to treat osteoporosis by enhancing bone remodeling, especially osteoblast function, resulting in enhanced trabecular bone parameters (179). In T2DM rats, intermittent parathyroid hormone treatment increases trabecular bone mass due to elevated bone formation and enhances bone defect regeneration (14).

Post hoc analyses from the dance study have shown that teriparatide decreases risk of fracture in diabetics similar to nondiabetic patients (180). However, the results on bone mineral density were surprising, showing a significantly greater effect of teriparatide at the femoral neck in diabetics vs nondiabetics. These data are supported by a recent study from Langdahl et al. (181), who found that teriparatide reduces vertebral, non-vertebral and femur fractures in diabetics. Given the mechanism of action, teriparatide should be the first-line treatment in diabetic patients after a fragility fracture. Improving bone formation but also gradually increasing bone resorption appears as an ideal order to reverse the low bone turnover state typical of long-term diabetes.

\section{Anti-sclerostin antibody}

Sclerostin is a negative regulator of bone mass by inhibiting osteoblastogenesis. In vivo studies show that treatment with anti-sclerostin antibody improves bone mass in healthy rodents and monkeys as well as in type 2 diabetic rats (reviewed in 182, 183). In diabetic ZDF rats, bone formation rate increases leading to an elevated bone mineral density and enhanced bone mechanical properties. In addition, bone defect healing was improved by anti-sclerostin antibody administration (15). In clinical trials, the anti-sclerostin antibody romosozumab increased bone mineral density and reduced fracture risk in postmenopausal women by increasing bone formation and transiently decreasing bone resorption. Therefore, this treatment option may be a good candidate for the treatment of diabetic bone disease. However, romosozumab treatment has been associated with an increased risk of cardiovascular events, which are common in T2DM patients, and therefore romosozumab needs to be critically tested for clinical use for T2DM (reviewed in $183,184)$.

\section{Conclusion}

Research over the past years has highlighted the detrimental effect of T2DM on bone quality and strength and has led to the acceptance of diabetic bone disease as a serious complication of long-standing T2DM. Despite recent progress in the understanding of the pathogenesis of diabetic bone disease, the mechanisms of action are far from being completely understood. Moreover, with the emergence of novel antidiabetic treatments, prospective studies are required to evaluate their effects on bone health and identify which treatments may require co-treatment with anti-osteoporosis medications. Thus, in light of the increasing prevalence of T2DM, more basic and clinical insights are required to maintain bone health of type 2 diabetics.
This work is licensed under a Creative Commons Attribution-NonCommercial 4.0 International License. ded from Bioscientifica.com at 04/25/2023 11:56:24PM via free access 


\section{Declaration of interest}

Martina Rauner is a senior editor for Endocrine Connections. She was not involved in the review or editorial process of this article, on which she is listed as an author. The other authors have nothing to disclose.

\section{Funding}

This work did not receive any specific grant from any funding agency in the public, commercial or not-for-profit sector.

\section{Acknowledgements}

All named authors take responsibility for the integrity of the work as a whole, and have given final approval for the version to be published. The figure is original and has been produced by the authors for this particular publication.

\section{References}

1 American Diabetes Association. Economic consequences of diabetes mellitus in the U.S. in 1997. Diabetes Care 199821 296-309. (https:// doi.org/10.2337/diacare.21.2.296)

2 International Diabetes Federation. IDF Diabetes Atlas, 8th ed. Brussels, Belgium: IDF, 2017.

3 Janghorbani M, Van Dam RM, Willett WC \& Hu FB. Systematic review of type 1 and type 2 diabetes mellitus and risk of fracture. American Journal of Epidemiology 2007166 495-505. (https://doi. org/10.1093/aje/kwm106)

4 Napoli N, Chandran M, Pierroz DD, Abrahamsen B, Schwartz AV, Ferrari SL \& IOF Bone and Diabetes Working Group. Mechanisms of diabetes mellitus-induced bone fragility. Nature Reviews Endocrinology 201713 208-219. (https://doi.org/10.1038/nrendo.2016.153)

5 Hofbauer LC, Brueck CC, Singh SK \& Dobnig H. Osteoporosis in patients with diabetes mellitus. Journal of Bone and Mineral Research 200722 1317-1328. (https://doi.org/10.1359/jbmr.070510)

6 Napoli N, Strotmeyer ES, Ensrud KE, Sellmeyer DE, Bauer DC, Hoffman AR, Dam TTL, Barrett-Connor E, Palermo L, Orwoll ES, et al. Fracture risk in diabetic elderly men: the MrOS study. Diabetologia 201457 2057-2065. (https://doi.org/10.1007/s00125-014-3289-6)

7 Napoli N, Schwartz AV, Black DM \& Osteoporotic Fractures in Men (MrOS) Study Research Group. Reply to: indications of increased vertebral fracture risk in patients with type 2 diabetes. Journal of Bone and Mineral Research 201833 183. (https://doi.org/10.1002/ jbmr.3322)

8 Napoli N, Jin J, Peters K, Wustrack R, Burch S, Chau A, Cauley J, Ensrud K, Kelly M \& Black DM. Are women with thicker cortices in the femoral shaft at higher risk of subtrochanteric/diaphyseal fractures? The study of osteoporotic fractures. Journal of Clinical Endocrinology and Metabolism 201297 2414-2422. (https://doi. org/10.1210/jc.2011-3256)

9 Purnamasari D, Puspitasari MD, Setiyohadi B, Nugroho P \& Isbagio $\mathrm{H}$. Low bone turnover in premenopausal women with type 2 diabetes mellitus as an early process of diabetes-associated bone alterations: a cross-sectional study. BMC Endocrine Disorders 201717 72. (https://doi.org/10.1186/s12902-017-0224-0)

10 Krakauer JC, McKenna MJ, Buderer NF, Rao DS, Whitehouse FW \& Parfitt AM. Bone loss and bone turnover in diabetes. Diabetes 1995 44 775-782. (https://doi.org/10.2337/diab.44.7.775)

11 Leite Duarte ME \& da Silva RD. Histomorphometric analysis of the bone tissue in patients with non-insulin-dependent diabetes (DMNID). Revista do Hospital das Clinicas 51 7-11.

12 Napoli N, Strollo R, Defeudis G, Leto G, Moretti C, Zampetti S, D'Onofrio L, Campagna G, Palermo A, Greto V, et al. Serum sclerostin and bone turnover in latent autoimmune diabetes in adults. Journal of Clinical Endocrinology and Metabolism 2018103 1921-1928. (https://doi.org/10.1210/jc.2017-02274)

13 Hygum K, Starup-Linde J, Harsløf T, Vestergaard P \& Langdahl BL. Mechanisms in endocrinology: diabetes mellitus, a state of low bone turnover - a systematic review and meta-analysis. European Journal of Endocrinology 2017176 R137-R157. (https://doi.org/10.1530/EJE-160652)

14 Hamann C, Picke AK, Campbell GM, Balyura M, Rauner M, Bernhardt R, Huber G, Morlock MM, Günther KP, Bornstein SR, et al. Effects of parathyroid hormone on bone mass, bone strength, and bone regeneration in male rats with type 2 diabetes mellitus. Endocrinology 2014155 1197-1206. (https://doi.org/10.1210/ en.2013-1960)

15 Hamann C, Rauner M, Höhna Y, Bernhardt R, Mettelsiefen J, Goettsch C, Günther KP, Stolina M, Han CY, Asuncion FJ, et al. Sclerostin antibody treatment improves bone mass, bone strength, and bone defect regeneration in rats with type 2 diabetes mellitus. Journal of Bone and Mineral Research 201328 627-638. (https://doi. org/10.1002/jbmr.1803)

16 Won HY, Lee JA, Park ZS, Song JS, Kim HY, Jang SM, Yoo SE, Rhee Y, Hwang ES \& Bae MA. Prominent bone loss mediated by RANKL and IL-17 produced by CD4+ T cells in TallyHo/JngJ mice. PLoS ONE 2011 6 e18168. (https://doi.org/10.1371/journal.pone.0018168)

17 Devlin MJ, Vliet M Van, Motyl K, Karim L, Brooks DJ, Louis L, Conlon C, Rosen CJ \& Bouxsein ML. Early-onset type 2 diabetes impairs skeletal acquisition in the male TALLYHO/JngJ mouse. Endocrinology 2014155 3806-3816. (https://doi.org/10.1210/ en.2014-1041)

18 Xu F, Dong Y, Huang X, Li M, Qin L, Ren Y, Guo F, Chen A \& Huang S. Decreased osteoclastogenesis, osteoblastogenesis and low bone mass in a mouse model of type 2 diabetes. Molecular Medicine Reports 201410 1935-1941. (https://doi.org/10.3892/ mmr.2014.2430)

19 Ma YHV, Schwartz AV, Sigurdsson S, Hue TF, Lang TF, Harris TB, Rosen CJ, Vittinghoff E, Eiriksdottir G, Hauksdottir AM, et al. Circulating sclerostin associated with vertebral bone marrow fat in older men but not women. Journal of Clinical Endocrinology and Metabolism 201499 E2584-E2590. (https://doi.org/10.1210/jc.20134493)

20 Janghorbani M, Feskanich D, Willett WC \& Hu F. Prospective study of diabetes and risk of hip fracture: the Nurses' Health Study. Diabetes Care 200629 1573-1578. (https://doi.org/10.2337/dc06-0440)

21 Forsén L, Meyer HE, Midthjell K \& Edna TH. Diabetes mellitus and the incidence of hip fracture: results from the Nord-Trøndelag Health Survey. Diabetologia 199942 920-925. (https://doi.org/10.1007/ s001250051248)

22 Ahmed LA, Joakimsen RM, Berntsen GK, Fønnebø V \& Schirmer H. Diabetes mellitus and the risk of non-vertebral fractures: the Tromsø study. Osteoporosis International 200617 495-500. (https://doi. org/10.1007/s00198-005-0013-x)

23 Patsch JM, Burghardt AJ, Yap SP, Baum T, Schwartz AV, Joseph GB $\&$ Link TM. Increased cortical porosity in type 2 diabetic postmenopausal women with fragility fractures. Journal of Bone and Mineral Research 201328 313-324. (https://doi.org/10.1002/ jbmr.1763)

24 Pritchard JM, Giangregorio LM, Atkinson SA, Beattie KA, Inglis D, Ioannidis G, Gerstein H, Punthakee Z, Adachi JD \& Papaioannou A. Changes in trabecular bone microarchitecture in postmenopausal women with and without type 2 diabetes: a two year longitudinal study. BMC Musculoskeletal Disorders 201314 114. (https://doi org/10.1186/1471-2474-14-114)

25 Pritchard JM, Giangregorio LM, Atkinson SA, Beattie KA, Inglis D, Ioannidis G, Punthakee Z, Adachi JD \& Papaioannou A. Association of larger holes in the trabecular bone at the distal radius in postmenopausal women with type 2 diabetes mellitus compared

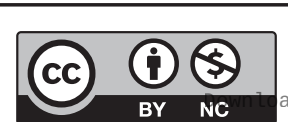

This work is licensed under a Creative Commons Attribution-NonCommercial 4.0 International License. ded from Bioscientifica.com at 04/25/2023 11:56:24PM 
to controls. Arthritis Care and Research 201264 83-91. (https://doi. org/10.1002/acr.20602)

26 Burghardt AJ, Issever AS, Schwartz AV, Davis KA, Masharani U, Majumdar S \& Link TM. High-resolution peripheral quantitative computed tomographic imaging of cortical and trabecular bone microarchitecture in patients with type 2 diabetes mellitus. Journal of Clinical Endocrinology and Metabolism 201095 5045-5055. (https:// doi.org/10.1210/jc.2010-0226)

27 Karim L \& Bouxsein ML. Effect of type 2 diabetes-related nonenzymatic glycation on bone biomechanical properties. Bone 2016 82 21-27. (https://doi.org/10.1016/j.bone.2015.07.028)

28 Farr JN, Drake MT, Amin S, Melton LJ, McCready LK \& Khosla S. In vivo assessment of bone quality in postmenopausal women with type 2 diabetes. Journal of Bone and Mineral Research 201429 787-795. (https://doi.org/10.1002/jbmr.2106)

29 Furst JR, Bandeira LC, Fan WW, Agarwal S, Nishiyama KK, McMahon DJ, Dworakowski E, Jiang H, Silverberg SJ \& Rubin MR. Advanced glycation endproducts and bone material strength in type 2 diabetes. Journal of Clinical Endocrinology and Metabolism 2016101 2502-2510. (https://doi.org/10.1210/jc.2016-1437)

30 Nordklint AK, Almdal TP, Vestergaard P, Lundby-Christensen L, Boesgaard TW, Breum L, Gade-Rasmussen B, Sneppen SB, Gluud C, Hemmingsen $\mathrm{B}$, et al. The effect of metformin versus placebo in combination with insulin analogues on bone mineral density and trabecular bone score in patients with type 2 diabetes mellitus: a randomized placebo-controlled trial. Osteoporosis International 2018 29 2517-2526. (https://doi.org/10.1007/s00198-018-4637-z)

31 Leslie WD, Aubry-Rozier B, Lamy O, Hans D \& Manitoba Bone Density Program. TBS (trabecular bone score) and diabetes-related fracture risk. Journal of Clinical Endocrinology and Metabolism 201398 602-609. (https://doi.org/10.1210/jc.2012-3118)

32 Kim JH, Choi HJ, Ku EJ, Kim KM, Kim SW, Cho NH \& Shin CS. Trabecular bone score as an indicator for skeletal deterioration in diabetes. Journal of Clinical Endocrinology and Metabolism 2015100 475-482. (https://doi.org/10.1210/jc.2014-2047)

33 Goldin A, Beckman JA, Schmidt AM \& Creager MA. Advanced glycation end products: sparking the development of diabetic vascular injury. Circulation 2006114 597-605. (https://doi. org/10.1161/CIRCULATIONAHA.106.621854)

34 Schmidt AM, Hori O, Chen JX, Li JF, Crandall J, Zhang J, Cao R, Yan SD, Brett J \& Stern D. Advanced glycation endproducts interacting with their endothelial receptor induce expression of vascular cell adhesion molecule-1 (VCAM-1) in cultured human endothelial cells and in mice. A potential mechanism for the accelerated vasculopathy of diabetes. Journal of Clinical Investigation 199596 1395-1403. (https://doi.org/10.1172/JCI118175)

35 Howard EW, Benton R, Ahern-Moore J \& Tomasek JJ. Cellular contraction of collagen lattices is inhibited by nonenzymatic glycation. Experimental Cell Research 1996228 132-137. (https://doi. org/10.1006/excr.1996.0308)

36 Poundarik AA, Wu PC, Evis Z, Sroga GE, Ural A, Rubin M \& Vashishth D. A direct role of collagen glycation in bone fracture. Journal of the Mechanical Behavior of Biomedical Materials 201552 120-130. (https://doi.org/10.1016/j.jmbbm.2015.08.012)

37 Garnero P, Borel O, Gineyts E, Duboeuf F, Solberg H, Bouxsein ML, Christiansen C \& Delmas PD. Extracellular post-translational modifications of collagen are major determinants of biomechanical properties of fetal bovine cortical bone. Bone 200638 300-309. (https://doi.org/10.1016/j.bone.2005.09.014)

38 Tang SY, Zeenath U \& Vashishth D. Effects of non-enzymatic glycation on cancellous bone fragility. Bone $2007 \mathbf{4 0} 1144-1151$. (https://doi.org/10.1016/j.bone.2006.12.056)

39 Saito M, Mori S, Mashiba T, Komatsubara S \& Marumo K. Collagen maturity, glycation induced-pentosidine, and mineralization are increased following 3-year treatment with incadronate in dogs. Osteoporosis International 200819 1343-1354. (https://doi. org/10.1007/s00198-008-0585-3)

40 Sanguineti R, Storace D, Monacelli F, Federici A \& Odetti P. Pentosidine effects on human osteoblasts in vitro. Annals of the New York Academy of Sciences 20081126 166-172. (https://doi. org/10.1196/annals.1433.044)

41 Ogawa N, Yamaguchi T, Yano S, Yamauchi M, Yamamoto M \& Sugimoto T. The combination of high glucose and advanced glycation end-products (AGEs) inhibits the mineralization of osteoblastic MC3T3-E1 cells through glucose-induced increase in the receptor for AGEs. Hormone and Metabolic Research 200739 871-875. (https://doi.org/10.1055/s-2007-991157)

42 Valcourt U, Merle B, Gineyts E, Viguet-Carrin S, Delmas PD \& Garnero P. Non-enzymatic glycation of bone collagen modifies osteoclastic activity and differentiation. Journal of Biological Chemistry 2007282 5691-5703. (https://doi.org/10.1074/jbc.M610536200)

43 Notsu M, Kanazawa I, Takeno A, Yokomoto-Umakoshi M, Tanaka KI, Yamaguchi T \& Sugimoto T. Advanced glycation end product 3 (AGE3) increases apoptosis and the expression of sclerostin by stimulating TGF- $\beta$ expression and secretion in osteocyte-like MLOY4-A2 cells. Calcified Tissue International 2017100 402-411. (https:// doi.org/10.1007/s00223-017-0243-x)

44 Tanaka K, Yamaguchi T, Kanazawa I \& Sugimoto T. Effects of high glucose and advanced glycation end products on the expressions of sclerostin and RANKL as well as apoptosis in osteocyte-like MLOY4-A2 cells. Biochemical and Biophysical Research Communications 2015461 193-199. (https://doi.org/10.1016/j.bbrc.2015.02.091)

45 Acevedo C, Sylvia M, Schaible E, Graham JL, Stanhope KL, Metz LN, Gludovatz B, Schwartz AV, Ritchie RO, Alliston TN, et al. Contributions of material properties and structure to increased bone fragility for a given bone mass in the UCD-T2DM rat model of type 2 diabetes. Journal of Bone and Mineral Research 201833 1066-1075. (https://doi.org/10.1002/jbmr.3393)

46 Verroken C, Zmierczak HG, Goemaere S, Kaufman JM \& Lapauw B. Insulin resistance is associated with smaller cortical bone size in nondiabetic men at the age of peak bone mass. Journal of Clinical Endocrinology and Metabolism 2017102 1807-1815. (https://doi. org/10.1210/jc.2016-3609)

47 Nilsson AG, Sundh D, Johansson L, Nilsson M, Mellström D, Rudäng R, Zoulakis M, Wallander M, Darelid A \& Lorentzon M. Type 2 diabetes mellitus is associated with better bone microarchitecture but lower bone material strength and poorer physical function in elderly women: a population-based study. Journal of Bone and Mineral Research 201732 1062-1071. (https://doi.org/10.1002/jbmr.3057)

48 Saito M, Fujii K, Mori Y \& Marumo K. Role of collagen enzymatic and glycation induced cross-links as a determinant of bone quality in spontaneously diabetic WBN/Kob rats. Osteoporosis International 2006 17 1514-1523. (https://doi.org/10.1007/s00198-006-0155-5)

49 Campbell GM, Tiwari S, Picke AK, Hofbauer C, Rauner M, Morlock MM, Hofbauer LC \& Glüer CC. Effects of insulin therapy on porosity, non-enzymatic glycation and mechanical competence in the bone of rats with type 2 diabetes mellitus. Bone 201691 186-193. (https://doi.org/10.1016/j.bone.2016.08.003)

50 Creecy A, Uppuganti S, Unal M, Clay Bunn R, Voziyan P \& Nyman JS. Low bone toughness in the TallyHO model of juvenile type 2 diabetes does not worsen with age. Bone 2018110 204-214. (https://doi.org/10.1016/j.bone.2018.02.005)

51 Hunt HB, Pearl JC, Diaz DR, King KB \& Donnelly E. Bone tissue collagen maturity and mineral content increase with sustained hyperglycemia in the KK-Ay murine model of type 2 diabetes. Journal of Bone and Mineral Research 201833 921-929. (https://doi. org/10.1002/jbmr.3365)

52 Makita Z, Radoff S, Rayfield EJ, Yang Z, Skolnik E, Delaney V, Friedman EA, Cerami A \& Vlassara H. Advanced glycosylation end products in patients with diabetic nephropathy. New England https://ec.bioscientifica.com https://doi.org/10.1530/EC-18-0456 (c) 2019 The authors Published by Bioscientifica Ltd

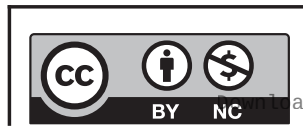

This work is licensed under a Creative Commons Attribution-NonCommercial 4.0 International License. ded from Bioscientifica.com at 04/25/2023 11:56:24PM 
Journal of Medicine 1991325 836-842. (https://doi.org/10.1056/ NEJM199109193251202)

53 Schwartz AV, Garnero P, Hillier TA, Sellmeyer DE, Strotmeyer ES, Feingold KR, Resnick HE, Tylavsky FA, Black DM, Cummings SR, et al. Pentosidine and increased fracture risk in older adults with type 2 diabetes. Journal of Clinical Endocrinology and Metabolism 200994 2380-2386. (https://doi.org/10.1210/jc.2008-2498)

54 Phimphilai M, Pothacharoen P, Kongtawelert P \& Chattipakorn N. Impaired osteogenic differentiation and enhanced cellular receptor of advanced glycation end products sensitivity in patients with type 2 diabetes. Journal of Bone and Mineral Metabolism 201735 631-641. (https://doi.org/10.1007/s00774-016-0800-9)

55 Choi YJ, Ock SY, Jin Y, Lee JS, Kim SH \& Chung YS. Urinary pentosidine levels negatively associates with trabecular bone scores in patients with type 2 diabetes mellitus. Osteoporosis International 201829 907-915. (https://doi.org/10.1007/s00198-017-4359-7)

56 Stolk RP, Van Daele PL, Pols HA, Burger H, Hofman A, Birkenhäger JC, Lamberts SW \& Grobbee DE. Hyperinsulinemia and bone mineral density in an elderly population: the Rotterdam study. Bone 199618 545-549. (https://doi.org/10.1016/87563282(96)00079-8)

57 Wei J, Shimazu J, Makinistoglu MP, Maurizi A, Kajimura D, Zong H, Takarada T, Lezaki T, Pessin JE, Hinoi E, et al. Glucose uptake and runx2 synergize to orchestrate osteoblast differentiation and bone formation. Cell 2015161 1576-1591. (https://doi.org/10.1016/j. cell.2015.05.029)

58 Napoli N, Strollo R, Paladini A, Briganti SI, Pozzilli P \& Epstein S. The alliance of mesenchymal stem cells, bone, and diabetes. International Journal of Endocrinology 20142014 690783. (https://doi. org/10.1155/2014/690783)

59 Klein GL. Insulin and bone: recent developments. World Journal of Diabetes 20145 14-16. (https://doi.org/10.4239/wjd.v5.i1.14)

60 Starup-Linde J \& Vestergaard P. Biochemical bone turnover markers in diabetes mellitus - a systematic review. Bone 201682 69-78. (https://doi.org/10.1016/j.bone.2015.02.019)

61 Jiffri EH. Impact of non-insulin dependent diabetes mellitus on bone structure biomarkers in postmenopausal obese women. Advances in Obesity, Weight Management and Control 20177 218-222. (https://doi. org/10.15406/aowmc.2017.07.00184)

62 Maghbooli Z, Shabani P, Gorgani-Firuzjaee S \& Hossein-Nezhad A. The association between bone turnover markers and microvascular complications of type 2 diabetes. Journal of Diabetes and Metabolic Disorders 201615 51. (https://doi.org/10.1186/s40200-016-0274-2)

63 Kulkarni SV, Meenatchi S, Reeta R, Ramesh R, Srinivasan AR \& Lenin C. Association of glycemic status with bone turnover markers in type 2 diabetes mellitus. International Journal of Applied and Basic Medical Research 7 247-251. (https://doi.org/10.4103/ijabmr. IJABMR_35_17)

64 Capoglu I, Ozkan A, Ozkan B \& Umudum Z. Bone turnover markers in patients with type 2 diabetes and their correlation with glycosylated haemoglobin levels. Journal of International Medical Research 36 1392-1398. (https://doi. org/10.1177/147323000803600629)

65 Miranda C, Giner M, Montoya MJ, Vázquez MA, Miranda MJ \& Pérez-Cano R. Influence of high glucose and advanced glycation endproducts (ages) levels in human osteoblast-like cells gene expression. BMC Musculoskeletal Disorders 201617 377. (https://doi.org/10.1186/ s12891-016-1228-z)

66 Ehnert S, Freude T, Ihle C, Mayer L, Braun B, Graeser J, Flesch I, Stöckle U, Nussler AK \& Pscherer S. Factors circulating in the blood of type 2 diabetes mellitus patients affect osteoblast maturation description of a novel in vitro model. Experimental Cell Research 2015 332 247-258. (https://doi.org/10.1016/j.yexcr.2014.12.011)

67 Kume S, Kato S, Yamagishi S, Inagaki Y, Ueda S, Arima N, Okawa T, Kojiro M \& Nagata K. Advanced glycation end-products attenuate human mesenchymal stem cells and prevent cognate differentiation into adipose tissue, cartilage, and bone. Journal of Bone and Mineral Research 200520 1647-1658. (https://doi.org/10.1359/JBMR.050514)

68 Alikhani M, Alikhani Z, Boyd C, MacLellan CM, Raptis M, Liu R, Pischon N, Trackman PC, Gerstenfeld L \& Graves DT. Advanced glycation end products stimulate osteoblast apoptosis via the MAP kinase and cytosolic apoptotic pathways. Bone $2007 \mathbf{4 0} 345-353$. (https://doi.org/10.1016/j.bone.2006.09.011)

69 López-Herradón A, Portal-Núñez S, García-Martín A, Lozano D, PérezMartínez FC, Ceña V \& Esbrit P. Inhibition of the canonical Wnt pathway by high glucose can be reversed by parathyroid hormonerelated protein in osteoblastic cells. Journal of Cellular Biochemistry 2013114 1908-1916. (https://doi.org/10.1002/jcb.24535)

70 Picke AK, Salbach-Hirsch J, Hintze V, Rother S, Rauner M, Kascholke C, Möller S, Bernhardt R, Rammelt S, Pisabarro MT, et al. Sulfated hyaluronan improves bone regeneration of diabetic rats by binding sclerostin and enhancing osteoblast function. Biomaterials 201696 11-23. (https://doi.org/10.1016/j.biomaterials.2016.04.013)

71 Picke AK, Rauner M, Hofbauer LC \& Hamann C. Eine hyperglykämie hemmt die osteoblastenfunktionen in vitro. Osteologie 201423 79-85. (https://doi.org/10.1055/s-0037-1620044)

72 Kim TY \& Schafer AL. Diabetes and bone marrow adiposity. Current Osteoporosis Reports 201614 337-344. (https://doi.org/10.1007/ s11914-016-0336-x)

73 Grey A, Beckley V, Doyle A, Fenwick S, Horne A, Gamble G \& Bolland M. Pioglitazone increases bone marrow fat in type 2 diabetes: results from a randomized controlled trial. European Journal of Endocrinology 2012166 1087-1091. (https://doi.org/10.1530/EJE11-1075)

74 Sheu Y, Amati F, Schwartz AV, Danielson ME, Li X, Boudreau R, Cauley JA \& Osteoporotic Fractures in Men (MrOS) Research Group. Vertebral bone marrow fat, bone mineral density and diabetes: the osteoporotic fractures in men (MrOS) study. Bone 201797 299-305. (https://doi.org/10.1016/j.bone.2017.02.001)

75 Hjortdahl P, Halstensen A, Høiby EA, Andrew M, Brandtzaeg P \& Gaustad P. The challenges of differential diagnosis of infections caused by beta-hemolytic streptococci. Tidsskrift for den Norske Laegeforening 1990110 2634-2637.

76 Hamann C, Goettsch C, Mettelsiefen J, Henkenjohann V, Rauner M, Hempel U, Bernhardt R, Fratzl-Zelman N, Roschger P, Rammelt $\mathrm{S}$, et al. Delayed bone regeneration and low bone mass in a rat model of insulin-resistant type 2 diabetes mellitus is due to impaired osteoblast function. American Journal of Physiology: Endocrinology and Metabolism 2011301 E1220-8. (https://doi.org/10.1152/ ajpendo.00378.2011)

77 Lattanzio S, Santilli F, Liani R, Vazzana N, Ueland T, Di Fulvio P, Formoso G, Consoli A, Aukrust P \& Davì G. Circulating dickkopf-1 in diabetes mellitus: association with platelet activation and effects of improved metabolic control and low-dose aspirin. Journal of the American Heart Association 20143 e001000. (https://doi.org/10.1161/ JAHA.114.001000)

78 Braga Gomes K, Fontana Rodrigues K \& Fernandes AP. The role of transforming growth factor-beta in diabetic nephropathy. International Journal of Medical Genetics 20142014 1-6. (https://doi. org/10.1155/2014/180270)

79 Kim S, Koga T, Isobe M, Kern BE, Yokochi T, Chin YE, Karsenty G, Taniguchi T \& Takayanagi H. Stat1 functions as a cytoplasmic attenuator of Runx2 in the transcriptional program of osteoblast differentiation. Genes and Development 200317 1979-1991. (https:// doi.org/10.1101/gad.1119303)

80 Khan MP, Singh AK, Joharapurkar AA, Yadav M, Shree S, Kumar H, Gurjar A, Mishra JS, Tiwari MC, Nagar GK, et al. Pathophysiological mechanism of bone loss in type 2 diabetes involves inverse regulation of osteoblast function by PGC-1 $\alpha$ and Skeletal muscle atrogenes: AdipoR1 as a potential target for reversing diabetesinduced osteopenia. Diabetes 201564 2609-2623. (https://doi. org/10.2337/db14-1611) 
81 Hardouin P, Rharass T \& Lucas S. Bone marrow adipose tissue: to be or not to be a typical adipose tissue? Frontiers in Endocrinology 20167 85. (https://doi.org/10.3389/fendo.2016.00085)

82 Dallas SL, Prideaux M \& Bonewald LF. The osteocyte: an endocrine cell ... and more. Endocrine Reviews 201334 658-690. (https://doi. org/10.1210/er.2012-1026)

83 Mabilleau G, Perrot R, Flatt PR, Irwin N \& Chappard D. High fat-fed diabetic mice present with profound alterations of the osteocyte network. Bone 201690 99-106. (https://doi.org/10.1016/j. bone.2016.06.008)

84 Villarino ME, Sánchez LM, Bozal CB \& Ubios AM. Influence of short-term diabetes on osteocytic lacunae of alveolar bone. A histomorphometric study. Acta Odontologica Latinoamericana 200619 23-28.

85 Winkler DG, Sutherland MK, Geoghegan JC, Yu C, Hayes T, Skonier JE, Shpektor D, Jonas M, Kovacevich BR, StaehlingHampton $\mathrm{K}$, et al. Osteocyte control of bone formation via sclerostin, a novel BMP antagonist. EMBO Journal 200322 6267-6276. (https:// doi.org/10.1093/emboj/cdg599)

86 Xiong J \& O'Brien CA. Osteocyte RANKL: new insights into the control of bone remodeling. Journal of Bone and Mineral Research 2012 27 499-505. (https://doi.org/10.1002/jbmr.1547)

87 Catalfamo DL, Britten TM, Storch DL, Calderon NL, Sorenson HL \& Wallet SM. Hyperglycemia induced and intrinsic alterations in type 2 diabetes-derived osteoclast function. Oral Diseases 201319 303-312. (https://doi.org/10.1111/odi.12002)

88 García-Martín A, Rozas-Moreno P, Reyes-García R, Morales-Santana S, García-Fontana B, García-Salcedo JA \& Muñoz-Torres M. Circulating levels of sclerostin are increased in patients with type 2 diabetes mellitus. Journal of Clinical Endocrinology and Metabolism 201297 234-241. (https://doi.org/10.1210/jc.2011-2186)

89 Silswal N, Touchberry CD, Daniel DR, McCarthy DL, Zhang S, Andresen J, Stubbs JR \& Wacker MJ. FGF23 directly impairs endothelium-dependent vasorelaxation by increasing superoxide levels and reducing nitric oxide bioavailability. American Journal of Physiology: Endocrinology and Metabolism 2014307 E426-E436. (https://doi.org/10.1152/ajpendo.00264.2014)

90 Ärnlöv J, Carlsson AC, Sundström J, Ingelsson E, Larsson A, Lind L \& Larsson TE. Serum FGF23 and risk of cardiovascular events in relation to mineral metabolism and cardiovascular pathology. Clinical Journal of the American Society of Nephrology 20138 781-786. (https://doi.org/10.2215/CJN.09570912)

$91 \mathrm{Hu}$ X, Ma X, Luo Y, Xu Y, Xiong Q, Pan X, Bao Y \& Jia W. Elevation in fibroblast growth factor 23 and its value for identifying subclinical atherosclerosis in first-degree relatives of patients with diabetes. Scientific Reports 20166 34696. (https://doi.org/10.1038/srep34696)

92 Tamasi JA, Arey BJ, Bertolini DR \& Feyen JHM. Characterization of bone structure in leptin receptor-deficient Zucker (fa/fa) rats. Journal of Bone and Mineral Research 200318 1605-1611. (https://doi. org/10.1359/jbmr.2003.18.9.1605)

$93 \mathrm{Xu} \mathrm{F}$, Ye YP, Dong YH, Guo FJ, Chen AM \& Huang SL. Inhibitory effects of high glucose/insulin environment on osteoclast formation and resorption in vitro. Journal of Huazhong University of Science and Technology 201333 244-249. (https://doi.org/10.1007/s11596-0131105-z)

94 Cunha JS, Ferreira VM, Maquigussa E, Naves MA \& Boim MA. Effects of high glucose and high insulin concentrations on osteoblast function in vitro. Cell and Tissue Research 2014358 249-256. (https://doi.org/10.1007/s00441-014-1913-x)

$95 \mathrm{Xu}$ J, Yue F, Wang J, Chen L \& Qi W. High glucose inhibits receptor activator of nuclear factor-кB ligand-induced osteoclast differentiation via downregulation of v-ATPase V0 subunit $\mathrm{d} 2$ and dendritic cell-specific transmembrane protein. Molecular Medicine Reports 201511 865-870. (https://doi.org/10.3892/mmr.2014.2807)

96 Chen YL, Qiao YC, Xu Y, Ling W, Pan YH, Huang YC, Geng LJ, Zhao HL \& Zhang XX. Serum TNF- $\alpha$ concentrations in type 2 diabetes mellitus patients and diabetic nephropathy patients: a systematic review and meta-analysis. Immunology Letters 2017186 52-58. (https://doi.org/10.1016/j.imlet.2017.04.003)

97 Goto H, Hozumi A, Osaki M, Fukushima T, Sakamoto K, Yonekura A, Tomita M, Furukawa K, Shindo H \& Baba H. Primary human bone marrow adipocytes support TNF- $\alpha$-induced osteoclast differentiation and function through RANKL expression. Cytokine 201156 662-668. (https://doi.org/10.1016/j.cyto.2011.09.005)

98 Kobayashi K, Takahashi N, Jimi E, Udagawa N, Takami M, Kotake S, Nakagawa N, Kinosaki M, Yamaguchi K, Shima N, et al. Tumor necrosis factor alpha stimulates osteoclast differentiation by a mechanism independent of the ODF/RANKL-RANK interaction. Journal of Experimental Medicine 2000191 275-286. (https://doi. org/10.1084/jem.191.2.275)

99 Fuller K, Murphy C, Kirstein B, Fox SW \& Chambers TJ. TNFalpha potently activates osteoclasts, through a direct action independent of and strongly synergistic with RANKL. Endocrinology 2002143 1108-1118. (https://doi.org/10.1210/endo.143.3.8701)

100 Oh SR, Sul OJ, Kim YY, Kim HJ, Yu R, Suh JH \& Choi HS. Saturated fatty acids enhance osteoclast survival. Journal of Lipid Research 2010 51 892-899. (https://doi.org/10.1194/jlr.M800626)

101 Cornish J, MacGibbon A, Lin JM, Watson M, Callon KE, Tong PC, Dunford JE, van der Does Y, Williams GA, Grey AB, et al. Modulation of osteoclastogenesis by fatty acids. Endocrinology 2008149 5688-5695. (https://doi.org/10.1210/en.2008-0111)

102 Scheller EL, Cawthorn WP, Burr AA, Horowitz MC \& MacDougald OA. Marrow adipose tissue: trimming the fat. Trends in Endocrinology and Metabolism 201627 392-403. (https://doi. org/10.1016/j.tem.2016.03.016)

103 Baum T, Yap SP, Karampinos DC, Nardo L, Kuo D, Burghardt AJ, Masharani UB, Schwartz AV, Li X \& Link TM. Does vertebral bone marrow fat content correlate with abdominal adipose tissue, lumbar spine bone mineral density, and blood biomarkers in women with type 2 diabetes mellitus? Journal of Magnetic Resonance Imaging 2012 35 117-124. (https://doi.org/10.1002/jmri.22757)

104 de Araújo IM, Salmon CEG, Nahas AK, Nogueira-Barbosa MH, Elias J $\&$ de Paula FJA. Marrow adipose tissue spectrum in obesity and type 2 diabetes mellitus. European Journal of Endocrinology 2017176 21-30. (https://doi.org/10.1530/EJE-16-0448)

105 Patsch JM, Li X, Baum T, Yap SP, Karampinos DC, Schwartz AV \& Link TM. Bone marrow fat composition as a novel imaging biomarker in postmenopausal women with prevalent fragility fractures. Journal of Bone and Mineral Research 201328 1721-1728. (https://doi.org/10.1002/jbmr.1950)

106 Kurtz TW, Morris RC \& Pershadsingh HA. The Zucker fatty rat as a genetic model of obesity and hypertension. Hypertension 198913 896-901. (https://doi.org/10.1161/01.HYP.13.6.896)

107 Picke AK, Gordaliza Alaguero I, Campbell GM, Glüer CC, SalbachHirsch J, Rauner M, Hofbauer LC \& Hofbauer C. Bone defect regeneration and cortical bone parameters of type 2 diabetic rats are improved by insulin therapy. Bone 201682 108-115. (https://doi. org/10.1016/j.bone.2015.06.001)

108 Picke AK, Sylow L, Møller LL V, Kjøbsted R, Schmidt FN, Steejn MW, Salbach-Hirsch J, Hofbauer C, Blüher M, Saalbach A, et al. Differential effects of high-fat diet and exercise training on bone and energy metabolism. Bone 2018116 120-134. (https://doi.org/10.1016/j. bone.2018.07.015)

109 Keats EC, Dominguez JM, Grant MB \& Khan ZA. Switch from canonical to noncanonical Wnt signaling mediates high glucoseinduced adipogenesis. Stem Cells 201432 1649-1660. (https://doi. org/10.1002/stem.1659)

110 Okamoto M, Udagawa N, Uehara S, Maeda K, Yamashita T, Nakamichi Y, Kato H, Saito N, Minami Y, Takahashi N, et al. Noncanonical Wnt5a enhances Wnt/ $\beta$-catenin signaling during osteoblastogenesis. Scientific Reports 20144 4493. (https://doi. org/10.1038/srep04493)

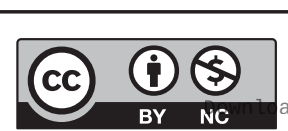

This work is licensed under a Creative Commons Attribution-NonCommercial 4.0 International License. ded from Bioscientifica.com at 04/25/2023 11:56:24PM 
111 Cawthorn WP, Bree AJ, Yao Y, Du B, Hemati N, MartinezSantibañez G \& MacDougald OA. Wnt6, Wnt10a and Wnt10b inhibit adipogenesis and stimulate osteoblastogenesis through a $\beta$-catenin-dependent mechanism. Bone 201250 477-489. (https:// doi.org/10.1016/j.bone.2011.08.010)

112 Ross SE, Hemati N, Longo KA, Bennett CN, Lucas PC, Erickson RL \& MacDougald OA. Inhibition of adipogenesis by Wnt signaling. Science 2000289 950-953. (https://doi.org/10.1126/ science.289.5481.950)

113 Song L, Liu M, Ono N, Bringhurst FR, Kronenberg HM \& Guo J. Loss of wnt/ $\beta$-catenin signaling causes cell fate shift of preosteoblasts from osteoblasts to adipocytes. Journal of Bone and Mineral Research 2012 27 2344-2358. (https://doi.org/10.1002/jbmr.1694)

114 Zhou J, Wang S, Qi Q, Yang X, Zhu E, Yuan H, Li X, Liu Y, Li X \& Wang B. Nuclear factor I-C reciprocally regulates adipocyte and osteoblast differentiation via control of canonical Wnt signaling. FASEB Journal 201731 1939-1952. (https://doi.org/10.1096/ fj.201600975RR)

115 Picke AK, Campbell GM, Blüher M, Krügel U, Schmidt FN, Tsourdi E, Winzer M, Rauner M, Vukicevic V, Busse B, et al. Thy-1 (CD90) promotes bone formation and protects against obesity. Science Translational Medicine 201810 eaao6806. (https://doi.org/10.1126/ scitranslmed.aao6806)

116 Piccinin MA \& Khan ZA. Pathophysiological role of enhanced bone marrow adipogenesis in diabetic complications. Adipocyte 3 263-272. (https://doi.org/10.4161/adip.32215)

117 Sarkar PD \& Choudhury AB. Relationships between serum osteocalcin levels versus blood glucose, insulin resistance and markers of systemic inflammation in central Indian type 2 diabetic patients. European Review for Medical and Pharmacological Sciences 201317 1631-1635.

118 Wellen KE \& Hotamisligil GS. Inflammation, stress, and diabetes. Journal of Clinical Investigation 2005115 1111-1119. (https://doi. org/10.1172/JCI25102)

119 Aguirre L, Napoli N, Waters D, Qualls C, Villareal DT \& ArmamentoVillareal R. Increasing adiposity is associated with higher adipokine levels and lower bone mineral density in obese older adults. Journal of Clinical Endocrinology and Metabolism 201499 3290-3297. (https:// doi.org/10.1210/jc.2013-3200)

120 Frommer K, Schäffler A, Lange U, Rehart S, Steinmeyer J, Rickert M, Müller-Ladner U \& Neumann E. 02.03 Influence of free fatty acids on osteoblasts and osteoclasts in rheumatic diseases. New Players and Novel Targets in Inflammation 2017 A9.1-A9. (https://doi.org/10.1136/ annrheumdis-2016-211050.3)

121 Regazzetti C, Peraldi P, Grémeaux T, Najem-Lendom R, Ben-Sahra I, Cormont M, Bost F, Le Marchand-Brustel Y, Tanti JF \& GiorgettiPeraldi S. Hypoxia decreases insulin signaling pathways in adipocytes. Diabetes 200958 95-103. (https://doi.org/10.2337/db08-0457)

122 Hosogai N, Fukuhara A, Oshima K, Miyata Y, Tanaka S, Segawa K, Furukawa S, Tochino Y, Komuro R, Matsuda M, et al. Adipose tissue hypoxia in obesity and its impact on adipocytokine dysregulation. Diabetes 200756 901-911. (https://doi.org/10.2337/db06-0911)

123 Wang B, Wood IS \& Trayhurn P. Dysregulation of the expression and secretion of inflammation-related adipokines by hypoxia in human adipocytes. Pflugers Archiv $2007 \mathbf{4 5 5}$ 479-492. (https://doi. org/10.1007/s00424-007-0301-8)

124 Kraakman MJ, Murphy AJ, Jandeleit-Dahm K \& Kammoun HL. Macrophage polarization in obesity and type 2 diabetes: weighing down our understanding of macrophage function? Frontiers in Immunology 20145 470. (https://doi.org/10.3389/fimmu.2014.00470)

125 Kusumbe AP, Ramasamy SK \& Adams RH. Coupling of angiogenesis and osteogenesis by a specific vessel subtype in bone. Nature 2014 507 323-328. (https://doi.org/10.1038/nature13145)

126 Oikawa A, Siragusa M, Quaini F, Mangialardi G, Katare RG, Caporali A, van Buul JD, van Alphen FPJ, Graiani G, Spinetti G, et al. Diabetes mellitus induces bone marrow microangiopathy. Arteriosclerosis, Thrombosis, and Vascular Biology 201030 498-508. (https://doi.org/10.1161/ATVBAHA.109.200154)

127 Fadini GP. An underlying principle for the study of circulating progenitor cells in diabetes and its complications. Diabetologia 2008 51 1091-1094. (https://doi.org/10.1007/s00125-008-1021-0)

128 Mangialardi G, Katare R, Oikawa A, Meloni M, Reni C, Emanueli C $\&$ Madeddu P. Diabetes causes bone marrow endothelial barrier dysfunction by activation of the RhoA-Rho-associated kinase signaling pathway. Arteriosclerosis, Thrombosis, and Vascular Biology 201333 555-564. (https://doi.org/10.1161/ATVBAHA.112.300424)

129 Ferraro F, Lymperi S, Méndez-Ferrer S, Saez B, Spencer JA, Yeap BY, Masselli E, Graiani G, Prezioso L, Rizzini EL, et al. Diabetes impairs hematopoietic stem cell mobilization by altering niche function. Science Translational Medicine 20113 104ra101. (https://doi. org/10.1126/scitranslmed.3002191)

130 Egan CG, Lavery R, Caporali F, Fondelli C, Laghi-Pasini F, Dotta F \& Sorrentino V. Generalised reduction of putative endothelial progenitors and CXCR4-positive peripheral blood cells in type 2 diabetes. Diabetologia 200851 1296-1305. (https://doi.org/10.1007/ s00125-008-0939-6)

131 Fadini GP, Miorin M, Facco M, Bonamico S, Baesso I, Grego F, Menegolo M, de Kreutzenberg SV, Tiengo A, Agostini C, et al. Circulating endothelial progenitor cells are reduced in peripheral vascular complications of type 2 diabetes mellitus. Journal of the American College of Cardiology 200545 1449-1457. (https://doi. org/10.1016/j.jacc.2004.11.067)

132 Spinetti G, Cordella D, Fortunato O, Sangalli E, Losa S, Gotti A, Carnelli F, Rosa F, Riboldi S, Sessa F, et al. Global remodeling of the vascular stem cell niche in bone marrow of diabetic patients: implication of the microRNA-155/FOXO3a signaling pathway. Circulation Research 2013112 510-522. (https://doi.org/10.1161/ CIRCRESAHA.112.300598)

133 Thum T, Fraccarollo D, Schultheiss M, Froese S, Galuppo P, Widder JD, Tsikas D, Ertl G \& Bauersachs J. Endothelial nitric oxide synthase uncoupling impairs endothelial progenitor cell mobilization and function in diabetes. Diabetes 200756 666-674. (https://doi.org/10.2337/db06-0699)

134 Tepper OM, Galiano RD, Capla JM, Kalka C, Gagne PJ, Jacobowitz GR, Levine JP \& Gurtner GC. Human endothelial progenitor cells from type II diabetics exhibit impaired proliferation, adhesion, and incorporation into vascular structures. Circulation 2002106 2781-2786. (https://doi.org/10.1161/01. CIR.0000039526.42991.93)

135 Cao C, Zhang H, Gong L, He Y \& Zhang N. High glucose conditions suppress the function of bone marrow-derived endothelial progenitor cells via inhibition of the eNOS-caveolin-1 complex. Molecular Medicine Reports 20125 341-346. (https://doi.org/10.3892/ mmr.2011.644)

136 Aicher A, Heeschen C, Mildner-Rihm C, Urbich C, Ihling C, TechnauIhling K, Zeiher AM \& Dimmeler S. Essential role of endothelial nitric oxide synthase for mobilization of stem and progenitor cells. Nature Medicine 20039 1370-1376. (https://doi.org/10.1038/nm948)

137 Berg AH \& Scherer PE. Adipose tissue, inflammation, and cardiovascular disease. Circulation Research 200596 939-949. (https:// doi.org/10.1161/01.RES.0000163635.62927.34)

138 Capla JM, Grogan RH, Callaghan MJ, Galiano RD, Tepper OM, Ceradini DJ \& Gurtner GC. Diabetes impairs endothelial progenitor cell-mediated blood vessel formation in response to hypoxia. Plastic and Reconstructive Surgery 2007119 59-70. (https://doi. org/10.1097/01.prs.0000244830.16906.3f)

139 Viollet B, Guigas B, Sanz Garcia N, Leclerc J, Foretz M \& Andreelli F. Cellular and molecular mechanisms of metformin: an overview. Clinical Science 2012122 253-270. (https://doi.org/10.1042/ CS20110386) https://ec.bioscientifica.com https://doi.org/10.1530/EC-18-0456 (c) 2019 The authors Published by Bioscientifica Ltd

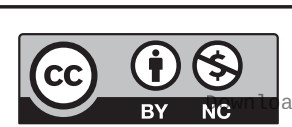

This work is licensed under a Creative Commons Attribution-NonCommercial 4.0 International License. ded from Bioscientifica.com at 04/25/2023 11:56:24PM 
140 Gilbert MP \& Pratley RE. The impact of diabetes and diabetes medications on bone health. Endocrine Reviews 201536 194-213. (https://doi.org/10.1210/er.2012-1042)

141 Palermo A, D'Onofrio L, Buzzetti R, Manfrini S \& Napoli N. Pathophysiology of bone fragility in patients with diabetes. Calcified Tissue International 2017100 122-132. (https://doi.org/10.1007/ s00223-016-0226-3)

142 Napoli N, Schwartz AV, Schafer AL, Vittinghoff E, Cawthon PM, Parimi N, Orwoll E, Strotmeyer ES, Hoffman AR, Barrett-Connor E, et al. Vertebral fracture risk in diabetic elderly men: the MrOS study. Journal of Bone and Mineral Research 201833 63-69. (https://doi. org/10.1002/jbmr.3287)

143 Stage TB, Christensen MMH, Jørgensen NR, Beck-Nielsen H, Brøsen K, Gram J \& Frost M. Effects of metformin, rosiglitazone and insulin on bone metabolism in patients with type 2 diabetes. Bone 2018112 35-41. (https://doi.org/10.1016/j.bone.2018.04.004)

144 Beck GR, Khazai NB, Bouloux GF, Camalier CE, Lin Y, Garneys LM, Siqueira J, Peng L, Pasquel F, et al. The effects of thiazolidinediones on human bone marrow stromal cell differentiation in vitro and in thiazolidinedione-treated patients with type 2 diabetes. Translational Research 2013161 145-155. (https://doi.org/10.1016/j. trsl.2012.08.006)

145 Losada-Grande E, Hawley S, Soldevila B, Martínez-Laguna D, Nogués X, Díez-Pérez A, Puig-Domingo M, Mauricio D \& PrietoAlhambra D. Insulin use and excess fracture risk in patients with type 2 diabetes: a propensity-matched cohort analysis. Scientific Reports 20177 3781. (https://doi.org/10.1038/s41598-017-03748-z)

146 Losada E, Soldevila B, Ali MS, Martínez-Laguna D, Nogués X, PuigDomingo M, Díez-Pérez A, Mauricio D \& Prieto-Alhambra D. Realworld antidiabetic drug use and fracture risk in 12,277 patients with type 2 diabetes mellitus: a nested case-control study. Osteoporosis International 201829 2079-2086. (https://doi.org/10.1007/s00198018-4581-y)

147 Schopman JE, Simon ACR, Hoefnagel SJM, Hoekstra JBL, Scholten RJPM \& Holleman F. The incidence of mild and severe hypoglycaemia in patients with type 2 diabetes mellitus treated with sulfonylureas: a systematic review and meta-analysis. Diabetes/ Metabolism Research and Reviews 201430 11-22. (https://doi. org/10.1002/dmrr.2470)

148 Starup-Linde J, Gregersen S, Frost M \& Vestergaard P. Use of glucoselowering drugs and risk of fracture in patients with type 2 diabetes. Bone 201795 136-142. (https://doi.org/10.1016/j.bone.2016.11.026)

149 Yamada C, Yamada Y, Tsukiyama K, Yamada K, Udagawa N, Takahashi N, Tanaka K, Drucker DJ, Seino Y \& Inagaki N. The murine glucagon-like peptide-1 receptor is essential for control of bone resorption. Endocrinology 2008149 574-579. (https://doi. org/10.1210/en.2007-1292)

150 Ma X, Meng J, Jia M, Bi L, Zhou Y, Wang Y, Hu J, He G \& Luo X. Exendin-4, a glucagon-like peptide-1 receptor agonist, prevents osteopenia by promoting bone formation and suppressing bone resorption in aged ovariectomized rats. Journal of Bone and Mineral Research 201328 1641-1652. (https://doi.org/10.1002/jbmr.1898)

151 Lu N, Sun H, Yu J, Wang X, Liu D, Zhao L, Sun L, Zhao H, Tao B \& Liu J. Glucagon-like peptide-1 receptor agonist Liraglutide has anabolic bone effects in ovariectomized rats without diabetes. PLOS ONE 201510 e0132744. (https://doi.org/10.1371/journal. pone.0132744)

152 Pereira M, Jeyabalan J, Jørgensen CS, Hopkinson M, Al-Jazzar A, Roux JP, Chavassieux P, Orriss IR, Cleasby ME \& Chenu C. Chronic administration of glucagon-like peptide-1 receptor agonists improves trabecular bone mass and architecture in ovariectomised mice. Bone 201581 459-467. (https://doi.org/10.1016/j.bone.2015.08.006)

153 Li J, Fu LZ, Liu L, Xie F \& Dai RC. Glucagon-like peptide-1 (GLP-1) receptor agonist liraglutide alters bone marrow exosome-mediated miRNA signal pathways in ovariectomized rats with type 2 diabetes. Medical Science Monitor 201723 5410-5419. (https://doi. org/10.12659/MSM.906603)

154 Wen B, Zhao L, Zhao H \& Wang X. Liraglutide exerts a boneprotective effect in ovariectomized rats with streptozotocininduced diabetes by inhibiting osteoclastogenesis. Experimental and Therapeutic Medicine 201815 5077-5083. (https://doi.org/10.3892/ etm.2018.6043)

155 Nuche-Berenguer B, Moreno P, Portal-Núñez S, Dapía S, Esbrit P \& Villanueva-Peñacarrillo ML. Exendin-4 exerts osteogenic actions in insulin-resistant and type 2 diabetic states. Regulatory Peptides 2010 159 61-66. (https://doi.org/10.1016/j.regpep.2009.06.010)

156 Nuche-Berenguer B, Moreno P, Esbrit P, Dapía S, Caeiro JR, Cancelas J, Haro-Mora JJ \& Villanueva-Peñacarrillo ML. Effect of GLP-1 treatment on bone turnover in normal, type 2 diabetic, and insulin-resistant states. Calcified Tissue International 200984 453-461. (https://doi.org/10.1007/s00223-009-9220-3)

157 Kim JY, Lee SK, Jo KJ, Song DY, Lim DM, Park KY, Bonewald LF \& Kim BJ. Exendin-4 increases bone mineral density in type 2 diabetic OLETF rats potentially through the down-regulation of SOST/ sclerostin in osteocytes. Life Sciences 201392 533-540. (https://doi. org/10.1016/j.lfs.2013.01.001)

158 Monami M, Dicembrini I, Antenore A \& Mannucci E. Dipeptidyl peptidase- 4 inhibitors and bone fractures: a meta-analysis of randomized clinical trials. Diabetes Care 201134 2474-2476. (https:// doi.org/10.2337/dc11-1099)

159 Mabilleau G, Mieczkowska A \& Chappard D. Use of glucagon-like peptide-1 receptor agonists and bone fractures: a meta-analysis of randomized clinical trials. Journal of Diabetes 20146 260-266. (https://doi.org/10.1111/1753-0407.12102)

160 Su B, Sheng H, Zhang M, Bu L, Yang P, Li L, Li F, Sheng C, Han Y, Qu S, et al. Risk of bone fractures associated with glucagonlike peptide-1 receptor agonists' treatment: a meta-analysis of randomized controlled trials. Endocrine 201548 107-115. (https:// doi.org/10.1007/s12020-014-0361-4)

161 Driessen JHM, de Vries F, van Onzenoort H, Harvey NC, Neef C, van Bergh JPW den, Vestergaard P \& Henry RMA. The use of incretins and fractures - a meta-analysis on population-based real life data. British Journal of Clinical Pharmacology 201783 923-926. (https://doi. org/10.1111/bcp.13167)

162 Iepsen EW, Lundgren JR, Hartmann B, Pedersen O, Hansen T, Jørgensen NR, Jensen JEB, Holst JJ, Madsbad S \& Torekov SS. GLP-1 receptor agonist treatment increases bone formation and prevents bone loss in weight-reduced obese women. Journal of Clinical Endocrinology and Metabolism 2015100 2909-2917. (https://doi. org/10.1210/jc.2015-1176)

163 Mosenzon O, Wei C, Davidson J, Scirica BM, Yanuv I, Rozenberg A, Hirshberg B, Cahn A, Stahre C, Strojek K, et al. Incidence of fractures in patients with type 2 diabetes in the SAVOR-TIMI 53 trial. Diabetes Care 201538 2142-2150. (https://doi.org/10.2337/dc15-1068)

164 Katsuno K, Fujimori Y, Takemura Y, Hiratochi M, Itoh F, Komatsu Y, Fujikura H \& Isaji M. Sergliflozin, a novel selective inhibitor of low-affinity sodium-glucose cotransporter (SGLT2), validates the critical role of SGLT2 in renal glucose reabsorption and modulates plasma glucose level. Journal of Pharmacology and Experimental Therapeutics 2007320 323-330. (https://doi. org/10.1124/jpet.106.110296)

165 Hummel CS, Lu C, Loo DDF, Hirayama BA, Voss AA \& Wright EM. Glucose transport by human renal $\mathrm{Na}+$ /D-glucose cotransporters SGLT1 and SGLT2. American Journal of Physiology: Cell Physiology 2011 300 C14-C21. (https://doi.org/10.1152/ajpcell.00388.2010)

166 Thrailkill KM, Clay Bunn R, Nyman JS, Rettiganti MR, Cockrell GE, Wahl EC, Uppuganti S, Lumpkin CK \& Fowlkes JL. SGLT2 inhibitor therapy improves blood glucose but does not prevent diabetic bone disease in diabetic DBA/2J male mice. Bone 201682 101-107. (https://doi.org/10.1016/j.bone.2015.07.025) https://ec.bioscientifica.com https://doi.org/10.1530/EC-18-0456 (c) 2019 The authors Published by Bioscientifica Ltd

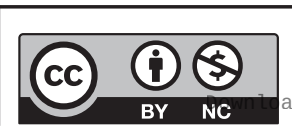

This work is licensed under a Creative Commons Attribution-NonCommercial 4.0 International License. ded from Bioscientifica.com at 04/25/2023 11:56:24PM 
167 Taylor SI, Blau JE \& Rother KI. Possible adverse effects of SGLT2 inhibitors on bone. Lancet. Diabetes and Endocrinology 2015 3 8-10. (https://doi.org/10.1016/S2213-8587(14)70227-X)

168 Bolinder J, Ljunggren Ö, Johansson L, Wilding J, Langkilde AM, Sjöström CD, Sugg J \& Parikh S. Dapagliflozin maintains glycaemic control while reducing weight and body fat mass over 2 years in patients with type 2 diabetes mellitus inadequately controlled on metformin. Diabetes, Obesity and Metabolism 201416 159-169. (https://doi.org/10.1111/dom.12189)

169 Ljunggren Ö, Bolinder J, Johansson L, Wilding J, Langkilde AM, Sjöström CD, Sugg J \& Parikh S. Dapagliflozin has no effect on markers of bone formation and resorption or bone mineral density in patients with inadequately controlled type 2 diabetes mellitus on metformin. Diabetes, Obesity and Metabolism 201214 990-999. (https://doi.org/10.1111/j.1463-1326.2012.01630.x)

170 Kohler S, Kaspers S, Salsali A, Zeller C \& Woerle HJ. Analysis of fractures in patients with type 2 diabetes treated with empagliflozin in pooled data from placebo-controlled trials and a head-to-head study versus glimepiride. Diabetes Care 201841 1809-1816. (https:// doi.org/10.2337/dc17-1525)

171 Watts NB, Bilezikian JP, Usiskin K, Edwards R, Desai M, Law G \& Meininger $\mathrm{G}$. Effects of canagliflozin on fracture risk in patients with type 2 diabetes mellitus. Journal of Clinical Endocrinology and Metabolism 2016101 157-166. (https://doi.org/10.1210/jc.20153167)

172 Bilezikian JP, Watts NB, Usiskin K, Polidori D, Fung A, Sullivan D $\&$ Rosenthal N. Evaluation of bone mineral density and bone biomarkers in patients with type 2 diabetes treated with canagliflozin. Journal of Clinical Endocrinology and Metabolism 2016 101 44-51. (https://doi.org/10.1210/jc.2015-1860)

173 Rachner TD, Khosla S \& Hofbauer LC. Osteoporosis: now and the future. Lancet 2011377 1276-1287. (https://doi.org/10.1016/S01406736(10)62349-5)

174 Dagdelen S, Sener D \& Bayraktar M. Influence of type 2 diabetes mellitus on bone mineral density response to bisphosphonates in late postmenopausal osteoporosis. Advances in Therapy $\mathbf{2 4}$ 1314-1320. (https://doi.org/10.1007/BF02877778)

175 Chandran M. Clinical aspects and management of osteoporosis and fragility fractures in patients with diabetes. Osteoporosis and Sarcopenia 20173 123-127. (https://doi.org/10.1016/j. afos.2017.08.101)
176 Anagnostis P, Paschou SA, Gkekas NN, Artzouchaltzi AM, Christou K, Stogiannou D, Vryonidou A, Potoupnis M \& Goulis DG. Efficacy of anti-osteoporotic medications in patients with type 1 and 2 diabetes mellitus: a systematic review. Endocrine $201860373-383$. (https:// doi.org/10.1007/s12020-018-1548-x)

177 Kostenuik PJ, Nguyen HQ, McCabe J, Warmington KS, Kurahara C, Sun N, Chen C, Li L, Cattley RC, Van G, et al. Denosumab, a fully human monoclonal antibody to RANKL, inhibits bone resorption and increases BMD in knock-in mice that express chimeric (murine/ human) RANKL. Journal of Bone and Mineral Research 200924 182-195. (https://doi.org/10.1359/jbmr.081112)

178 Napoli N, Pannacciulli N, Vittinghoff E, Crittenden D, Yun J, Wang A, Wagman R \& Schwartz AV. Effect of denosumab on fasting glucose in women with diabetes or prediabetes from the FREEDOM trial. Diabetes/Metabolism Research and Reviews 201834 e2991. (https://doi.org/10.1002/dmrr.2991)

179 Thomas T. Intermittent parathyroid hormone therapy to increase bone formation. Joint, Bone, Spine 200673 262-269. (https://doi. org/10.1016/j.jbspin.2005.11.007)

180 Schwartz AV, Pavo I, Alam J, Disch DP, Schuster D, Harris JM \& Krege JH. Teriparatide in patients with osteoporosis and type 2 diabetes. Bone 201691 152-158. (https://doi.org/10.1016/j.bone.2016.06.017)

181 Langdahl BL, Silverman S, Fujiwara S, Saag K, Napoli N, Soen S, Enomoto H, Melby TE, Disch DP, Marin F, et al. Real-world effectiveness of teriparatide on fracture reduction in patients with osteoporosis and comorbidities or risk factors for fractures: integrated analysis of 4 prospective observational studies. Bone 2018116 58-66. (https://doi.org/10.1016/j.bone.2018.07.013)

182 Drake MT \& Farr JN. Inhibitors of sclerostin: emerging concepts. Current Opinion in Rheumatology 201426 447-452. (https://doi. org/10.1097/BOR.0000000000000073)

183 Sølling ASK, Harsløf T \& Langdahl B. The clinical potential of romosozumab for the prevention of fractures in postmenopausal women with osteoporosis. Therapeutic Advances in Musculoskeletal Disease 201810 105-115. (https://doi.org/10.1177/17597 20X18775936)

184 Liu Y, Cao Y, Zhang S, Zhang W, Zhang B, Tang Q, Li Z \& Wu J. Romosozumab treatment in postmenopausal women with osteoporosis: a meta-analysis of randomized controlled trials. Climacteric 201821 189-195. (https://doi.org/10.1080/13697137.201 $8.1433655)$

Received in final form 21 January 2019 Accepted 24 January 2019 (c) 2019 The authors Published by Bioscientifica Ltd

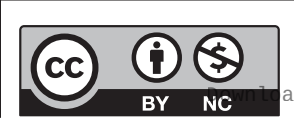

This work is licensed under a Creative Commons Attribution-NonCommercial 4.0 International License. ded from Bioscientifica.com at 04/25/2023 11:56:24PM 